\title{
ESSENTIAL AND CONDITIONALLY-ESSENTIAL NUTRIENTS IN CLINICAL NUTRITION
}

\author{
GEORGE K. GRIMBLE
}

Department of Gastroenterology \& Nutrition, Central Middlesex Hospital, Acton Lane, London NW10 7NS

\section{CONTENTS}

WHAT CONSTITUTES A CONDITIONALLY-ESSENTIAL NUTRIENT? . 97 AMINO ACIDS AND RELATED COMPOUNDS . . . . . . . . . 98

GLUTAMINE

Glutamine and acidosis . . . . . . . . . . . . . . . . . 101

Interorgan glutamine flows in response to acidosis inflammatory mediators and trauma . . . . . . . . . . . . . 102

Glutamine and urea salvage . . . . . . . . . . . . . . . . . . . . . 103

ARGININE . . . . . . . . . . . . . . . . . . 103

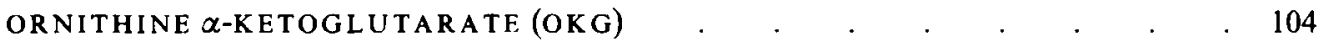

NUCLEIC ACIDS . . . . . . . . . . . . . . . . . . . . 106

PURINE AND PYRIMIDINE BIOSYNTHESIS, SALVAGE AND CATABOLISM · 106

RELATIVE RATES OF SALVAGE AND DE NOVO SYNTHESIS OF PURINES AND

PYRIMIDINES .

NUCLEOTIDE REQUIREMENTS FOR CELLULAR GROWTH . . . . . . 107

EXOGENOUS NUCLEOTIDES IN GROWTH-ESSENTIAL OR NOT? . . . 108

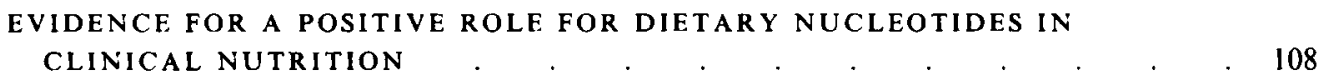

Infection and immune function . . . . . . . . . . . . . . . . . . 109

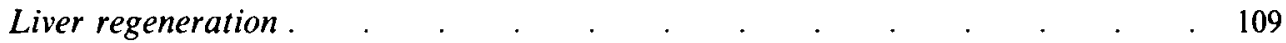

Intestinal repair .

EXOGENOUS NUCLEOTIDES IN CLINICAL SITUATIONS-ESSENTIAL OR
NOT?

SHORT CHAIN FATTY ACIDS . . . . . . . . . . . . . . . . $\quad . \quad 110$

METABOLIC IMPORTANCE OF SHORT CHAIN FATTY ACIDS IN THE COLON . 110

THE CLINICAL SIGNIFICANCE OF SCFA SUPPLEMENTATION OF COLONIC

LUMINAL CONTENTS . . . . . . . . . . . . . . . . 111

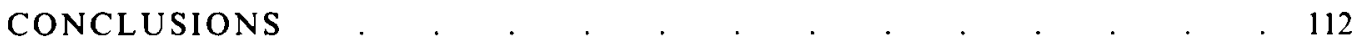

REFERENCES . . . . . . . . . . . . . . . . 112

\section{WHAT CONSTITUTES A CONDITIONALLY-ESSENTIAL NUTRIENT?}

An essential nutrient can be defined as one whose absence from the diet will lead to growth impairment, organ dysfunction or failure to maintain nitrogen balance on an adequate intake of all other nutrients. This simple definition has proved useful in considering vitamin 
or fatty acid requirements in infants but has led to confusion with regard to macronutrients. The basic metabolic difficulty is that for some substrates, although a synthetic pathway can be demonstrated, it may be rate limiting for growth conditions which lead to a markedly increased demand for synthesis. This has led to the concept of 'conditional essentiality' under clinical conditions of stress due to growth, infection or trauma. This new term has been extremely productive in stimulating research, for two reasons. Firstly, some animal models will exhibit signs of deficiency following surgical trauma (e.g. arginine (Seifter et al. 1978)) identifying avenues of research into human trauma. Secondly, it allows definition of animal models in which organ dysfunction can be observed, particularly when reduced function (e.g. increased intestinal permeability, reduced hepatic capacity to maintain a low arterial $\mathrm{NH}_{4}^{+}$concentration) is truly pathological, rather than within the normal range of physiological adaptation.

This review will attempt to define the proper grounds on which a nutrient may be considered 'conditionally-essential' in man. This will be applied to the 'novel substrates' which are currently proposed as clinically useful adjuncts. These include glutamine, arginine, ornithine $\alpha$-ketoglutarate (OKG), nucleotides and the short chain fatty acids (SCFA) which have, variously, been described as conditionally-essential nutrients, functional nutrients, nutraceutics, pseudonutrients or even as agents 'supporting' some aspect of body metabolism.

Table 1 describes one set of criteria for assessing whether a nutrient can be classed as conditionally-essential, and provides a starting point for discussion. In general the criteria should be observed regardless of the species used as an experimental model, although exceptions may occur. Agreement of criteria is important because an inappropriate definition of conditional essentiality may affect clinical perceptions and treatment strategy. Thus use of the alternative definition of a therapeutically useful molecule (e.g. lactulose or lactitol for treatment of hepatic encephalopathy) means that the issue becomes pharmacological and not nutritional. This simple set of criteria also avoids teleological arguments which have dogged the discussion of infant requirements. The identification of minor components in breast milk has resulted in their being considered as conditionallyessential nutrients. This has been the case with nucleotides (Jimenez et al. 1992), polyamines (Pollack et al. 1992; Romain et al. 1992) and the casomorphin peptide sequence from casein, which stimulates electrolyte uptake in the ileum, slows gastric emptying and has immunostimulatory properties (Jaziri et al. 1992). All have been shown to have positive biological value for the intestine and could be classed as functional or conditionallyessential nutrients in the newborn, but this teleological approach has at least one obvious pitfall. Many compounds diffuse from the maternal circulation into milk, an example being capsaicin from peppers, which can increase gastric motility (Raybould, 1991), but has never been considered as a conditionally-essential nutrient.

\section{AMINO ACIDS AND RELATED COMPOUNDS}

Rose and colleagues first classified amino acids into essential and non-essential categories, on the basis that their carbon skeletons could not be synthesized endogenously (Rose, 1937). In contrast, those which could be synthesized from other amino acids or metabolites were classified as non-essential, or dispensable. This clear division of amino acids has been refined over the years (Munro, 1964; Jackson, 1982; Laidlaw \& Kopple, 1987; Millward et al. 1989). While an adequate growth rate in the young animal is a sensitive indicator of nutritional adequacy and allows easy identification of essentiality, dietary amino acid adequacy in healthy adults or patients in the clinical setting has proved far less easy to define (Millward et al. 1989). 
Table 1. Criteria for conditionally-essential nutrients

Failure to maintain growth or nitrogen balance

Organ dysfunction

Delayed recovery

Metabolic abnormalities

Clinical abnormalities
Deficiency will result in:

In the young or the malnourished, traumatized or septic patient

In healthy subjects or malnourished, traumatized or septic patients

After trauma or sepsis

In healthy subjects or malnourished, traumatized or septic patients

In malnourished, traumatized or septic patients

Demonstration of semi-essentiality has been observed in neonatal infants receiving standard total parenteral nutrition (TPN) regimens, in whom imbalances in the ratio of plasma methionine and cysteine have been observed (Helms et al. 1987). This can be related to poor conversion of methionine to cysteine, secondary to low tissue levels of the enzyme, cystathionase (EC 4.4.1.1), at birth (Gaull et al. 1972). There is no evidence of any dietary need for cysteine in the healthy adult. In addition, age related changes in amino acid requirements are complicated by species differences. Thus growth retardation will occur if arginine is omitted from the diet of young cats (MacDonald et al. 1984) and the young of a group of other species (see Barbul, 1986) but not man (Nakagawa et al. 1963). Thus, some species may not be an ideal model for assessing conditional essentiality as defined in Table 1 .

In addition, the classical definition that essentiality is conferred by the carbon skeleton (Rose, 1957) has been revised in terms of the need to consider the relative availability and dispensability of the amino group (Jackson, 1982; Laidlaw \& Kopple, 1987; Millward et al. 1989). Thus the capacity of enzymic pathways for transamination of essential amino acids or synthesis of non-essential amino acids to meet demand under all dietary or clinical circumstances needs to be considered, and this leads to identification of conditional essentiality in man (Table 2).

\section{GLUTAMINE}

Glutamine has been described as a 'conditionally-essential amino acid' (Fürst et al. 1987; Souba, 1993) because of the marked changes which occur in its tissue distribution in traumatized patients. During episodes of severe abdominal sepsis, the marked fall in the muscle intracellular glutamine concentration correlates with the severity of the patient's condition (Roth et al. 1982). Furthermore, in rats the characteristics of the muscle plasma-membrane glutamine transporter are modulated by stress and catabolic hormones in such a way that the intracellular glutamine concentration correlates with the rate of muscle protein synthesis (Rennie et al. 1986; Jepson et al. 1988). This was an unusual finding because of its implication that the intracellular concentration of an amino acid previously considered non-essential may control disposal of essential amino acids into protein synthesis. In addition, cultured cells will not grow well in glutamine deficient media because, as argued by McKeehan, the metabolism of these cells is directed not towards a high rate of glycolysis and lactate production but towards the use of glutamine as a primary metabolic fuel (McKeehan, 1992). This seems to be the case for other cell lines with a high rate of turnover, such as enterocytes (Souba et al. 1985a), or the macrophages and dividing lymphocytes found in gut associated lymphatic tissue (Newsholme et al. 1985; Newsholme \& Newsholme, 1989; Szondy \& Newsholme, 1990). An adequate supply of glutamine may 
Table 2. Classification of amino acids according to essentiality

\begin{tabular}{|c|c|c|}
\hline \multirow[b]{2}{*}{ Amino group } & \multicolumn{2}{|c|}{ Carbon skeleton } \\
\hline & Essential & Non-essential \\
\hline Essential & $\begin{array}{l}\text { Lysine } \\
\text { Threonine }\end{array}$ & $\begin{array}{l}\text { Serine } \\
\text { Glycine* } \\
\text { Cysteine* }\end{array}$ \\
\hline \multirow[t]{11}{*}{ Non-essential } & $\begin{array}{l}\text { Branched chain amino } \\
\text { acids }\end{array}$ & Glutamate \\
\hline & Tryptophan & Alanine \\
\hline & Phenylalanine & Aspartate \\
\hline & Methionine & Glutamine \\
\hline & & Asparagine \\
\hline & & Proline* \\
\hline & & Tyrosine ${ }^{*}$ \\
\hline & & Histidine* \\
\hline & & Arginine* \\
\hline & & Serine* \\
\hline & & Taurine* \\
\hline
\end{tabular}

Adapted from (Jackson, 1983; Millward et al. 1989; Laidlaw \& Kopple, 1987).

* May become conditionally-essential because of limitations in rate of synthesis.

therefore be necessary for immune responsiveness (Newsholme \& Parry-Billings, 1990), or for maintenance of the mucosal barrier against ingress of endotoxins or bacteria (Fink, 1991).

In the growing rat, replacement of casein in the diet with an amino acid mixture simulating it, but lacking glutamine (glutamate and $\mathrm{NH}_{4}{ }^{+}$substitution), had no effect on any growth parameters (Itoh et al. 1973). In addition, during TPN of the piglet, addition of glutamine or glutamate had no effect on any nutritional parameter or aspect of gut morphology (Burrin et al. 1991). This effect is species dependent because marked morphological changes can be observed in the rat fed solely by TPN (Tamada et al. 1992) and these are reversed by glutamine supplementation. However, in the mouse or man (Guedon et al. 1986) fed by TPN, the absence of intestinal luminal nutrients reduced brush border hydrolase concentrations and villus height, but without any sign of morphological pathology.

This suggests that in three of these four species in vivo glutamine synthesis is sufficient to supply intestinal requirements (Golden et al. 1982) and that it may be produced from a variety of metabolic precursors (Grimble et al. 1992). Changes in plasma and muscle intracellular glutamine concentrations consequent on injury, sepsis, or acidosis may therefore reflect a shift in interorgan flow of glutamine but with no overall change in the rate of whole body glutamine synthesis (Squires \& Brosnan, 1983).

Several animal and clinical studies have assessed the ability of glutamine supplementation to improve or maintain various aspects of organ function in response to sepsis or trauma, and an attempt has been made to integrate the confusing picture presented by recent clinical trials of supplemental feeds (Souba et al. 1990). Certainly, where this function has been severely impaired by methotrexate, or by radiation, rats receiving a glutamine supplemented enteral diet showed significantly reduced mortality (Fox et al. 1988), improved morphology (Klimberg et al. $1990 a, b$ ) or reduced translocation of enteral bacteria to the mesenteric lymph nodes (Karatzas et al. 1991), compared to unsupplemented control animals. Hypovolumic shock induced by partial exsanguination was reversed by luminal glutamine 
Table 3. Effect of trauma on ratio of urinary urea nitrogen to total urinary nitrogen excretion $(U U N / T U N)$

\begin{tabular}{|c|c|c|}
\hline Patient group & $\begin{array}{c}\text { UUN/TUN (\%) } \\
\text { Mean } \pm \text { SD (Range) }\end{array}$ & Reference \\
\hline $\begin{array}{l}\text { Healthy volunteers } \\
\text { Postoperative } \\
\text { Multiple trauma } \\
\text { Pancreatitis } \\
\text { Critically ill } \\
\text { Nitrogen excretion }<5 \mathrm{~g} / \mathrm{d} \\
\text { Nitrogen excretion } 5 \cdot 10 \mathrm{~g} / \mathrm{d} \\
\text { Nitrogen excretion } 10-15 \mathrm{~g} / \mathrm{d} \\
\text { Nitrogen excretion }>15 \mathrm{~g} / \mathrm{d} \\
\text { All patients }\end{array}$ & $\begin{array}{l}84 \cdot 0 \pm 10 \cdot 2(70100) \\
72 \cdot 7 \pm 15 \cdot 8(25-95) \\
79 \cdot 9 \pm 6 \cdot 4(73 \cdot 89) \\
77 \cdot 0 \pm 9 \cdot 2(61-90) \\
\quad- \\
75 \cdot 0 \pm 20 \\
82 \cdot 5 \pm 10 \cdot 5 \\
85 \cdot 0 \pm 12 \cdot 5 \\
87 \cdot 5 \pm 10 \cdot 0 \\
80 \cdot 5 \pm 13 \cdot 5(1098)\end{array}$ & Konstantanides et al. 1991 \\
\hline
\end{tabular}

or glucose infusion (Flynn et al. 1992). In addition, the atrophy of the small intestine which occurs in rats maintained on TPN can be reversed by glutamine supplementation in the form of the dipeptide alanylglutamine (Tamada et al. 1992). This atrophic effect is species dependent since no effect of glutamine supplementation has been observed in piglets (Burrin et al. 1991). Following gastrointestinal surgery, glutamine supplementation of TPN solutions has also been shown to moderate postoperative net efflux of glutamine from muscle and increased urinary nitrogen excretion, compared to that in patients fed by standard regimens (Stehle et al. 1989; Hammarqvist et al. 1989a). The most recent prospective controlled trial of glutamine supplemented TPN has shown reduced urinary lactulose/mannitol ratios as an index of intestinal permeability (cf. unsupplemented controls) although this can be partly explained by the marked difference in mannitol permeation between groups (van der Hulst et al. 1993).

These data therefore provide a framework for the suggestion that increased glutamine release from skeletal muscle following trauma may serve to supply it as an essential nutrient for cells of the immune system or for the gut itself (Wilmore et al. 1988; Newsholme \& Parry-Billings 1990). Certainly, the rapid fall in muscle intracellular glutamine concentration which follows surgery can be counteracted by glutamine supplementation of TPN regimens (Hammarquist et al. 1988, 1989a; Stehle et al. 1989). However, what is missing from this analysis is the nature of the signal which links the two processes, and evidence that de novo glutamine synthesis and circulating concentrations can be reduced to such an extent that target organ function is severely impaired. A recent study showed that partial removal of the intestine did not reduce skeletal muscle glutamine efflux, which casts some doubt on a gut-muscle signalling cycle (Deutz et al. 1992a).

\section{Glutamine and acidosis}

A powerful signal for changes in glutamine homeostasis is acidosis, consequent on injury, surgery or infection. Acidosis is accompanied by increased $\mathrm{NH}_{4}{ }^{+}$excretion. Each turn of the liver urea cycle consumes 2 molecules of both $\mathrm{NH}_{4}{ }^{+}$and $\mathrm{HCO}_{3}{ }^{-}$, derived from oxidation of amino acids. Acidosis increases $\mathrm{HCO}_{3}{ }^{-}$consumption, providing an alternative route for $\mathrm{HCO}_{3}{ }^{-}$excretion. Thus, increased urinary $\mathrm{NH}_{4}{ }^{+}$excretion reflects the base deficit of metabolic acidosis. The impact of injury, surgery or infection on acidosis can be demonstrated by comparing the effects of surgical injury (Leander et al. 1985) or infusion with a triple hormone regimen of glucagon, cortisol and adrenalin (Bessey et al. 1984) or experimental acidosis (Fine et al. 1978), or long term starvation (Owen et al. 1969; Giesecke 
et al. 1989) or in utero nutrient deprivation (Wolfe et al. 1989) on urinary nitrogen and $\mathrm{NH}_{4}{ }^{+}$excretion. Because of advances in rapid, automated methods of measuring urinary total nitrogen excretion, the effectiveness of urinary urea nitrogen (UUN) as an accurate measure of total urinary nitrogen (TUN) excretion has been tested in two large studies (Grimble et al. 1988; Konstantanides et al. 1991). UUN is a poor surrogate for nitrogen excretion in stressed, septic or traumatized patients. For groups of patients classified by disease status, UUN/TUN (\%) may be reduced slightly (Table 3), but within each group the variance is very wide. Most of the nitrogen 'gap' between UUN and TUN in patients can be accounted for by increased $\mathrm{NH}_{4}{ }^{+}$excretion (Burge et al. 1992) and points to a high incidence of subclinical acidosis. The truth of this hypothesis cannot be tested at present, because there are few clinical nutrition studies in disease states (other than those affecting renal function; Rustom et al. 1992) in which longitudinal evolution of $\mathrm{NH}_{4}^{+}$excretion has been measured.

\section{Interorgan glutamine flows in response to acidosis, inflammatory mediators and trauma}

Under normal physiological circumstances, meal feeding induces net glutamine synthesis and efflux by skeletal muscle (Elia \& Livesey, 1983). The anatomical hierarchy of the liver is adapted to this in that there are two distinct cell populations, clustered at periportal and perivenous sites, which serve different purposes. As described by Haussinger and colleagues, net glutamine cycling between these two cell populations efficiently amplifies the signal for increased urea synthesis, that is portal $\mathrm{NH}_{4}{ }^{+}$concentration (Haussinger et al. 1992). This signal appears to be dependent on intestinal consumption of glutamine from arterial or luminal sources (Windmueller, 1982; Souba \& Wilmore, 1983; Souba et al. 1985b; Jahoor et al. 1988).

Acidosis in the rat is accompanied by a fall in circulating glutamine. Despite this, there are increases in the main agents of glutamine consumption (renal phosphate dependent glutaminase $E C$ 3.5.1.2) and production (muscle glutamine synthetase (EC 6.3.1.2); King et al. 1983). In man, renal glutamine consumption and $\mathrm{NH}_{4}{ }^{+}$generation are both increased by acidosis, which markedly depresses plasma glutamine concentration (Pitts \& Pilkington, 1966; Welbourne et al. 1982). Normally, in man renal glutamine consumption is only a small part of whole body glutamine turnover ( $\sim 2 \%$; Golden et al. 1982) but this increases threefold in chronic $\mathrm{NH}_{4} \mathrm{Cl}$-induced acidosis (Owen \& Robinson, 1963; Tizianello et al. 1978). If sustained, this would lead to excess nitrogen excretion of the order of 4-5 $\mathrm{g} /$ day unless there were a counterbalancing reduction in urea production.

Following surgery or trauma there is net release of amino acids from muscle, and their consumption by the tissues of the hepato-splanchnic region. In addition, in the immediate postoperative period, muscle intracellular glutamine concentration falls precipitately, as does plasma concentration, and this cannot be reversed by simple feeding (Wernerman $e t$ al. 1987).

Acidosis can be invoked as the underlying mechanism for most of these changes during surgery or trauma for three reasons. Firstly it has been observed to occur with even the mildest forms of surgery, such as laparoendoscopic cholecystectomy (Liu et al. 1991) and can be detected as a local event signalling ischaemia of the gastric mucosa in critically ill patients (Fiddian Green et al. 1991). Secondly, the septic rat displays one hallmark of acidosis, i.e. increased renal glutaminase concentration (Ardawi et al. 1991) which is not related to endotoxaemia (Austgen et al. 1991). Unfortunately, the most complete study to date, on postoperative changes in organ flows of amino acids in pigs, omitted any measurement of renal glutamine balance but gave evidence of increased arterial $\mathrm{NH}_{4}^{+}$ concentration. There was marked efflux of glutamine from skeletal muscle, increased liver uptake and marked spleen uptake with reduced intestinal glutamine consumption (Deutz 
et al. 1992b). Finally, the mechanisms by which tubular cells secrete $\mathrm{NH}_{4}{ }^{+}, \mathrm{Ca}^{2+}$ and inorganic phosphorus into the lumen are stimulated both by prior induction of acidosis and by cortisol (Boross et al. 1986). The original demonstration that a triple infusion of cortisol, glucagon and adrenalin could mimic the pattern of post-traumatic urinary nitrogen excretion (Bessey et al. 1984) has been confirmed and extended to demonstrate that peripheral amino acid release is increased (Wernerman et al. 1985). Furthermore, administration of the triple hormone mixture to healthy volunteers fed by TPN elicited increased lactate efflux from peripheral tissues and lactic acidosis (Fong et al. 1991). That this may be sufficient to cause net amino acid release from muscle is suggested by three studies. Metabolic acidosis in the rat was accompanied by increased muscle protein degradation in vitro, which was mediated by cortisol or by simple reduction in the $\mathrm{pH}$ of the incubation medium (May et al. 1986). In vivo, the rate of muscle protein synthesis is acutely depressed by respiratory acidosis (Preedy et al. 1988). This phenomenon applies to protein degradation as well, since an increase in $\mathrm{pH}$ will depress it whilst increasing protein synthesis in the working, perfused rat heart (Fuller et al. 1989). In man, dogs and rats, acidosis increases the rate of whole body protein breakdown (e.g. Reaich et al. 1992), similar to the effects of acidosis secondary to chronic renal failure (Garibotto et al. 1992).

The consequence of this analysis is that glutamine status, per se, reflects not signs of a nutritional deficiency or the conditionally-essential nature of the amino acid, but merely a new set point in response to the underlying metabolic disturbance of injury.

\section{Glutamine and urea salvage}

Urea can diffuse into the colon to be hydrolysed by bacterial urease to $\mathrm{NH}_{4}{ }^{+}$, and since little is lost as faecal $\mathrm{N}$, it provides a source of nitrogen for resynthesis of the $\alpha-\mathrm{NH}_{2}$ group of amino acids. This is a considerable source of portal $\mathrm{NH}_{4}{ }^{+}$, estimated at $2.6 \mathrm{~g} \mathrm{~N} / \mathrm{d}$ in comparison to a daily urea production rate of $8.5 \mathrm{~g} \mathrm{~N}$ from an intake of $14 \mathrm{~g}$ protein $\mathrm{N}$ (Jackson et al. 1984; Moran \& Jackson, 1990; Danielsen \& Jackson, 1992). The exact metabolic fate of this salvaged nitrogen has yet to be quantified but it can be assumed to be returned to the amino acid pool via the glutamate dehydrogenase $(E C 1.4 .1 .2)$ reaction and subsequent transamination. Infants and adults, receiving low dietary nitrogen intakes which will not support growth or nitrogen balance, can be maintained in positive nitrogen balance by urea supplementation (Snyderman et al. 1962; Kies, 1972). This is clearly a significant contribution to blood $\mathrm{NH}_{4}{ }^{+}$flux, in addition to that derived from intestinal consumption of glutamine.

In the fasted, intravenously fed patient, receiving concurrent antibiotic therapy, this route of nitrogen recycling will be markedly reduced (van Berlo et al. 1988). It would be tempting to speculate that glutamine supplementation may partly replace this, since intestinal consumption is proportional to arterial load (Windmueller, 1982) and part of the $\mathrm{NH}_{4}{ }^{+}$produced will diffuse freely into the lumen and back into the portal circulation (Soeters \& van Leeuwen, 1986).

\section{ARGININE}

The essentiality of arginine for growth is species dependent (see Visek, 1986; Barbul, 1986) but has not been demonstrated in man. Its essentiality is most obvious in the cat (MacDonald et al. 1984), presumably because of its poor capacity for renal arginine synthesis from citrulline and ornithine of intestinal origin (Lund, 1980; Brosnan, 1987). In adult man, this situation does not pertain because, as suggested by Lund, "synthesis of citrulline from glutamine is interesting from the nutritional point of view, because it provides an explanation as to why arginine is not an essential amino acid in the adult' 
(Lund, 1980). The suggestion that arginine might be conditionally essential arose from the observations that in mice and rats supplementation markedly improved immune responsiveness (Barbul, 1986; Barbul et al. 1990). A prospective controlled clinical trial of enteral supplementation $(25 \mathrm{~g} / \mathrm{d})$ showed increased lymphocyte response to phytohaemagglutinin and patients were maintained in better nitrogen balance than their glycine supplemented controls (Daly et al. 1988). Healing of a standard wound inflicted on healthy volunteers was more rapid (in a dose response fashion) after arginine supplementation (Barbul et al. 1990). Similarly, diets supplemented with arginine, RNA and fish oil reduced the incidence of postoperative septic complications and increased lymphocyte phytohaemagglutinin responsiveness in surgical patients (Daly et al. 1992).

These data suggest a role for arginine in traumatized patients but its mechanism of action is probably multifactorial (Kirk \& Barbul, 1990). It seems likely that an important action of arginine is through its metabolite, nitric oxide. This gas is a potent, short-lived mediator which controls endothelial tone (Palmer et al. 1987; Vallance et al. 1989). Its pathway of synthesis comprises inducible and non-inducible elements, the former being related directly to arginine supply (Aisaki et al. 1989; Moritoki et al. 1992). Local effects of nitric oxide generation on gastrointestinal barrier function are marked: in several animal models of mucosal injury induced by ischaemia reperfusion or chemical agents it has been consistently shown that permeability is increased, or mucosal injury is further potentiated if the nitric oxide synthase $(E C 1.14 .13 .39)$ inhibitor $\mathrm{N}^{\mathrm{G}}$-nitro-L-arginine-methyl ester was administered (Boughton Smith et al. 1992; Kubes, 1992, 1993; Miller et al. 1993). In addition, nitric oxide stimulates small bowel motility, an important stripping mechanism for preventing bacterial enteroadherence (Calignano et al. 1992). These data may explain the old observation that L-arginine (but not D-arginine) markedly stimulates net water secretion in the perfused jejunum in man (Hegarty et al. 1981), since nitric oxide cannot be synthesized from D-arginine (Vallance et al. 1989). It is possible that part of the clinical effects of arginine in the studies described above was related to its ability to maintain gut barrier function against ingress of bacteria or endotoxins.

A second aspect of the action of arginine in patients receiving nutrition support is its ability to potentiate growth hormone secretion (Merimee et al. 1969). Certainly, growth hormone therapy has been shown to reverse negative nitrogen balance, and loss of muscle glutamine and functioning ribosomes, in burned and postoperative patients (Wilmore $e t$ al. 1974; Ziegler et al. 1988; Ponting et al. 1990; Hammarqvist et al. 1992).

It would appear then that whatever the therapeutic mode of action of arginine in trauma patients (Barbul et al. 1990), it does not relate to any question of essentiality, since similar positive effects of arginine supplementation have been observed in healthy adult volunteers (Barbul, 1986).

\section{ORNITHINE $\alpha$-KETOGLUTARATE (OKG)}

OKG comprises two molecules of the dibasic amino acid, ornithine (a urea cycle intermediate), and one molecule of $\alpha$-ketoglutarate (a Krebs cycle intermediate). It has been observed to improve nutritional status of selected groups of patients (Trémolières $e t$ al. 1972; Brocker et al. 1985). In two prospective controlled trials, supplementation of TPN regimens with OKG improved nitrogen balance and reversed the effects of surgical trauma on skeletal muscle (Leander et al. 1985; Hammarqvist et al. 1989 b). Its mode of action (Cynober, 1991) can be described in terms of 'push-pull' mechanisms. The 'push' mechanisms would be the generation of intermediary metabolites with stimulatory or permissive effects on macromolecular biosynthesis. These include proline, arginine, 

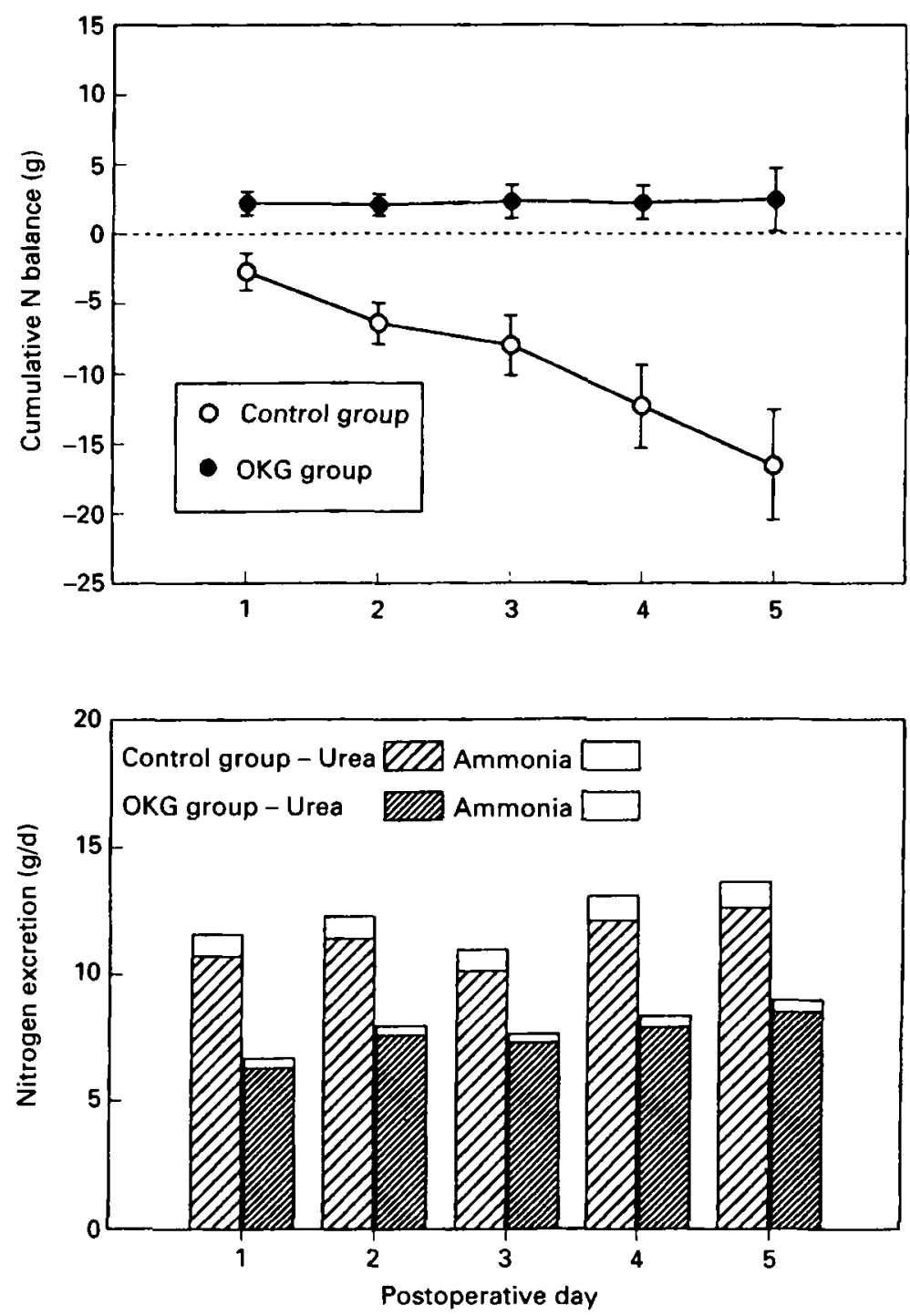

Fig. 1. Effect of supplementation of postoperative total parenteral nutrition (TPN) with ornithine $\alpha$ ketoglutarate $(\mathrm{OKG})$ on nitrogen excretion in patients undergoing colectomy. TPN regimens were isonitrogenous and contained supplements of either $2.5 \mathrm{~g}$ nitrogen as OKG or mixed L-amino acids.

Upper panel: Cumulative nitrogen balance. Lower panel: Urinary urea and $\mathrm{NH}_{4}^{*}$ excretion. Data taken from Leander et al. 1985.

glutamine, ketoacids and, in addition, polyamines. The 'pull' mechanism is represented by the stimulation of anabolic hormone secretion, that is insulin and growth hormone (Krassowski et al. 1981; Jeevanandam et al. 1991). In clinical studies of patients suffering from trauma (Jeevanandam et al. 1992), cirrhosis (Lambert, 1982) or in children with growth defects (Lecointre \& Dailly, 1981), OKG increased average plasma growth hormone concentrations (Jeevanandam et al. 1992).

It is possible that $\mathrm{OKG}$ may also exert an influence on nitrogen balance in postoperative patients through its influence on acid-base balance. The data shown in Fig. 1 are from a 
study in which postoperative patients received either standard TPN solutions or TPN in which part of the amino acids had been replaced with OKG (Leander et al. 1985). The treatment moderated the normal catabolic response to this type of surgery, as it did following cholecystectomy (Wernerman et al. 1987). Glutamine or arginine supplementation was equally effective (Elsair et al. 1978; Daly et al. 1988; Hammarqvist et al. 1989a). Excess excretion of urinary nitrogen after injury was inhibited by OKG supplementation, which maintained patients in slight positive nitrogen balance (upper panel). Other indicators of trauma, such as depletion of intracellular muscle glutamine concentration and a reduced number of muscle ribosomes engaged in protein synthesis, were also partly reversed (Wernerman et al. 1987, 1990). What is especially intriguing is that OKG reversed the mild metabolic acidosis (increased $\mathrm{NH}_{4}{ }^{+}$excretion) which is a consequence of injury.

The effect of supplemental $\alpha$-ketoglutarate on $\mathrm{NH}_{4}{ }^{+}$excretion is most understandable because of the reciprocal relationship between $\mathrm{NH}_{4}{ }^{+}$excretion and renal intramitochondrial $\alpha$-ketoglutarate concentration in acidosis (Lowry \& Ross, 1980; Vinay et al. 1980) and through its inhibitory effects on renal mitochondrial glutamine uptake (Goldstein et al. 1977). The importance of $\alpha$-ketoglutarate in maintaining $\mathrm{NH}_{4}^{+}$homeostasis is also suggested by the relationship between a low plasma concentration and the onset of hyperammonaemia in infants with defects in urea cycle enzymes (Batshaw et al. 1980). It should also be noted that only OKG, not glutamine or protein, has been shown to normalize acid-base balance in starved rats (Ziegler et al. 1992).

\section{NUCLEIC ACIDS}

Nucleic acids are not thought to be essential nutrients, since pathways exist for synthesis of purines and pyrimidines de novo. Nevertheless, there is persuasive experimental evidence that nucleotide supplementation of enteral (Kulkarni et al. 1986; Uauy et al. 1990) and parenteral (Ogoshi et al. 1985; Iijima et al. 1992) nutrients, which are commonly nucleotide free, has positive effects on organ growth and the ability of animals to resist infection or recover from major surgery. The relevant questions which should therefore be addressed relate to the nature of purine and pyrimidine requirements and whether endogenous purine and pyrimidine supply can ever be exceeded by demand in the acutely ill patient.

\section{PURINE AND PYRIMIDINE BIOSYNTHESIS, SALVAGE AND CATABOLISM}

Endogenous purines and pyrimidines are synthesized de novo from amino acids and other small molecules (D’Mello, 1982; Giesecke \& Tiemeyer, 1982; Zöllner, 1982). Pyrimidines are synthesized from $\mathrm{NH}_{3}, \mathrm{CO}_{2}$ and aspartate (the latter being synthesized from glutamine in lymphocytes; Wu \& Greene, 1992), while purines utilize two amide $\mathrm{N}$ of glutamine, nitrogen from glycine and aspartate and carbon from $\mathrm{CO}_{2}$, formate, glycine and aspartate.

Degradation of the 5'-mono-, di- and triphosphates occurs through the stepwise removal of phosphate and ribose (or 2'-deoxyribose) to form the nucleobases, uracil, cytosine (pyrimidines) or hypoxanthine (purines). Salvage of the nucleobases occurs by a single step addition of 5-phosphoribosyl-1-pyrophosphate to form the 5'-monophosphate (hypoxanthine-guanosine phosphoribosyl transferase $(E C 2.4 .2 .8)$. Purine catabolism appears to be controlled by intracellular 5-phosphoribosyl-1-pyrophosphate levels, the activity of the phosphoribosylamidotransferase $(E C 2.4 .2 .14)$ and the intracellular concentrations of IMP, AMP and GMP (Zöllner, 1982). An adequate intracellular concentration of 
nucleotide monophosphates will inhibit the first step in purine synthesis, an adequate supply of the 5-phosphoribosyl-1-pyrophosphate will activate it.

\section{RELATIVE RATES OF SALVAGE AND DE NOVO SYNTHESIS OF PURINES AND PYRIMIDINES}

Whole animal isotopic studies provide some information. Uptake of dietary purines and pyrimidines and their incorporation into tissues is surprisingly modest (D'Mello, 1982). Even though there are intestinal transport mechanisms for all four purine/pyrimidine bases and nucleosides, their capacity is limited and excess of oral intake is malabsorbed and metabolized by colonic luminal microflora (Schanker, et al. 1963; Greife \& Molnar, 1983; Scharrer et al. 1984; Roden et al. 1991). In contrast, intravenously infused ${ }^{14} \mathrm{C}$-labelled purines are efficiently assimilated into tissue nucleic acids, especially those organs with high cell turnover (e.g. salivary, adrenal, thyroid, thymus and pituitary glands and lymph tissue) (Savaiano et al. 1980; Ogoshi et al. 1988). The intestine is thus capable of specifically modifying dietary nucleotide intake, as has been shown by active incorporation of $\left[{ }^{14} \mathrm{C}\right] \mathrm{adenine}$ into intestinal nucleic acids, whereas guanine, hypoxanthine and xanthine were extensively catabolized during transmucosal passage (Sonoda \& Tatibana, 1978; Savaiano \& Clifford, 1981). Furthermore, there is a reciprocal relationship between purine intake and de novo synthesis in the gut (LeLeiko et al. 1979, 1983) which only holds when there is an adequate dietary protein intake to supply substrate for de novo synthesis (Gross et al. 1988; Ghiggeri et al. 1990).

Studies of turnover of cellular RNA also provide some information in that attempts to measure precursor enrichments in incorporation studies have shown precursor pool compartmentation with different precursor pools for mRNA and rRNA synthesis (small/non-expandable and large/expandable) in Ehrlich ascites cells (Genchev et al. 1980), HeLa S3 cells (Wiegers et al. 1976), regenerating rat liver (Ove et al. 1966) and rat hepatoma cells (Losman \& Harley, 1978). The small pool is nucleolar (rRNA synthesis) and supplied mainly by de novo synthesis (Wiegers et al. 1976) while the large pool can be supplied by either de novo synthesis or by salvage of exogenous supply (Goody \& Ellem, 1975).

Extensive salvage of nucleotides would mean that RNA turnover studies involving isotopic decay would result in isotope reutilization and underestimation of turnover compared with incorporation methods. In fact, incorporation studies by this author and others (Grimble \& Millward, 1977; Grimble, 1981; Morgan et al. 1985), using $\left[{ }^{14} \mathrm{C}\right]$ methylmethionine as the methylation precursor for rRNA in liver, skeletal muscle and heart in an attempt to circumvent the problem of compartmentation, indicate calculated rates of turnover which are surprisingly independent of the isotope or method of administration, suggesting that de novo synthesis of purines and pyrimidines in vivo makes a small contribution to the supply of RNA precursors.

\section{NUCLEOTIDE REQUIREMENTS FOR CELLULAR GROWTH}

Circumstances associated with marked increases in cellular growth such as the regenerating liver (Loeb \& Yeung, 1975), regrowth of the contralateral kidney following unilateral nephrectomy (Hill et al. 1974), 'catch-up' growth of muscle in protein depleted animals (Millward et al. 1975) or work induced skeletal muscle hypertrophy (Laurent $e t$ al. 1978) all have the common feature of early and extensive changes in cellular ribosome 
content or ribosome synthesis which usually precede those of protein, often by a considerable margin (Grimble, 1981 ; Bates et al. 1983 Ashford \& Pain, 1986). Ribosomal RNA is the most abundant species and accounts for the largest requirement for de novo synthesis and salvage of purines and pyrimidines. In these circumstances in which manyfold increases in ribosome synthesis occur there are obvious demands for nucleotide precursors, although reduction in nucleolar wastage of $45 \mathrm{~S}$ precursor rRNA (pre-rRNA) may limit the requirements for de novo synthesis of purines and pyrimidines (e.g. Hill, 1975). Similar considerations apply to cells of the immune system, which must also increase ribosome synthesis before cell division and immunoglobulin synthesis can occur. In vitro stimulation of cultured lymphocytes with phytohaemagglutin, a widely used assay for immune competence in postoperative patients (Daly et al. 1992), represents an extreme anabolic stimulus since the rate of ribosome synthesis increases rapidly, 10-50 times that seen in resting lymphocytes (Cooper, 1972). De novo synthesis provides most of the nucleotide flux for increased RNA and DNA synthesis in the phytohaemagglutinin stimulated lymphocyte as suggested by the limited ability of exogenous nucleobases and nucleosides (i.e. the salvage pathway) to relieve inhibition of growth by limiting amounts of glutamine in the culture medium (de novo pathway; Szondy \& Newsholme, 1990).

\section{EXOGENOUS NUCLEOTIDES IN GROWTH-ESSENTIAL OR NOT?}

In all of these growth or inflammatory circumstances, whilst the requirements for nucleic acid synthesis may be a small component of overall cellular needs for substrate, because RNA synthesis precedes any changes in protein synthesis it is of paramount importance. Where protein intake is adequate, de novo synthesis may well provide the main source of nucleotides for nucleic acid synthesis. Although it can be suppressed by dietary purine and pyrimidine supply, the degree to which this occurs depends on the tissue type. Liver and gut behave differently. In liver dietary purines increase the activities of salvage and catabolism pathways simultaneously. Also when protein intake is reduced, salvage is increased. Ribosomal RNA production appears to rely more heavily on de novo synthesis than does mRNA or tRNA synthesis, indicating that this major component of RNA turnover is, like protein turnover, controlled by the dietary amino acid supply. In contrast the gut, which has only a low capacity for de novo synthesis, is dependent on the liver for its supply of nucleotides. Thus lack of dietary purines and pyrimidines will only switch on de novo synthesis in this tissue to a limited extent, and the salvage pathway assumes a greater importance as a means of recycling purines and pyrimidines released by nucleic acid catabolism. Indeed, it could be argued that because of the reliance of rRNA synthesis on de novo pathways, and the low levels of these pathways in the enterocyte, cell turnover should be particularly sensitive to any limitation of purine and pyrimidine supply.

\section{EVIDENCE FOR A POSITIVE ROLE FOR DIETARY NUCLEOTIDES IN CLINICAL NUTRITION}

Most enteral and all parenteral regimens have lacked nucleotides. Furthermore, few patients acutely admitted to hospital are adapted to such a diet and are presumably more reliant on exogenous (salvage) pathways due to a pre-existing intake of purine- and pyrimidine-rich foods. Does nucleotide supplementation have any clinical significance in allowing such patients to mount an appropriate inflammatory response to trauma or sepsis? Dietary supplementation with nucleotides, nucleosides or nucleobases can improve growth rate and nitrogen retention in young animals (György, 1971; Greife et al. 1984). 
Furthermore, four lines of evidence suggest that supplementation with dietary or parenteral nucleotides/nucleosides may be of clinical significance.

\section{Infection and immune function}

Overall, experimental studies of the effects of nucleotide supplementation on immune cell responsiveness have been difficult to relate to the clinical setting. On the one hand the whole animal studies which show reduced mortality after nucleotide supplementation are highly suggestive. Thus mean survival time after i.v. injection of Candida albicans in mice receiving a nucleotide free diet was significantly increased with additions of yeast RNA or individual nucleobases (Fanslow et al. 1988). In contrast nucleotide free diets were immunosuppressive in irradiated mice studied in terms of the degree of fatal graft $v$. host reactions (Kulkarni et al. 1986), since mortality from reactions was significantly reduced and the nucleotide free diets reduced the responsiveness of lymphocytes to phytohaemagglutinins to a very marked extent.

\section{Liver regeneration}

It would appear that repair and growth in the liver, a major organ of purine and pyrimidine biosynthesis, can be improved by providing an external supply of preformed nucleotides and nucleosides. Thus, supplementation of TPN regimens with nucleotides and nucleosides (as 10\% of amino acid nitrogen), given after $70 \%$ hepatectomy in rats, significantly improved postoperative nitrogen balance and whole body protein turnover and synthesis (Ogoshi et al. 1990). Supplementation also reduced the extent of galactosamine induced liver injury (Ogoshi et al. 1988).

\section{Intestinal repair}

Nucleotide supplementation has been shown to improve parameters of intestinal maturation in weaning rats (Uauy et al. 1990) and can partly reverse the mucosal damage secondary to chronic lactose administration to rats, at least in terms of a partial restoration of the atrophy of the small intestine at both proximal and distal ends (Nunez et al. 1990). The intestinal atrophy which results from TPN (Richter et al. 1983) can be partly reversed by nucleotide supplementation of the intravenous regimen in rats (lijima et al. 1993).

\section{EXOGENOUS NUCLEOTIDES IN CLINICAL SITUATIONS-ESSENTIAL OR NOT?}

It is evident from the above that no clear conclusion can be reached as to whether dietary nucleotide supplementation is likely to be of benefit in the clinical setting. This has not prevented the formulation and use of specific 'stress diets' which include nucleotide supplementation (with arginine and fish oil), with promising results in postoperative patients (Daly et al. 1992). Indeed, the teleological argument has been advanced to explain reciprocal increases and decreases in liver and gut consumption, respectively, on the grounds that increased liver uptake reflects the need to supply nucleotide precursors and glutathione for cell repair in the gut and liver (Austgen et al. 1991). Normal diets probably provide sufficient purines and pyrimidines to allow for any such limitation; indeed, 'requirements' are probably quite modest given the tight metabolic control of purine synthesis and degradation and low utilization of dietary sources. TPN or enteral nutrition is unusual in that no purines or pyrimidines are given even though the patient's pre-existing diet would have conditioned purine and pyrimidine metabolism to 'salvage' rather than de novo synthesis. 
The few relevant studies cited above are quite persuasive and can only serve to promote further studies, especially those with involvement of the gut (barrier function) or immune system.

\section{SHORT CHAIN FATTY ACIDS}

\section{METABOLIC IMPORTANCE OF SHORT CHAIN FATTY ACIDS IN THE COLON}

Production of SCFA in the colon occurs during fermentation by colonic microorganisms. The colonic luminal bacteria, described as an 'organ-within-an-organ', and the associated luminal SCFA develop slowly during the first two years of life in human infants (Midtvedt \& Midtvedt, 1992), at a rate which depends on the diet with marked differences between breast fed and formula fed infants. Thus the process is complete by 1 month in formula fed infants and by 9 months in the breast fed infant in whom there is better absorption of macronutrients from breast milk and a relative lack of colonic luminal nutrients. Indicators of fermentation of malabsorbed protein (iso- and $n$-valeric acids) are not fully adapted until 16 months of life (Midtvedt \& Midtvedt, 1992).

It is important to recognize that SCFA may not necessarily be the major organic anion group generated within the colonic lumen. Analysis of luminal organic acids is usually by gas chromatography which will only detect the volatile SCFA, not lactate and the dicarboxylic acids. Although SCFA make a substantial contribution to the tonicity of luminal contents $(260 \mathrm{mOsm} / 1$ and $180 \mathrm{mOsm} / 1$ in the caecum and rectum respectively (Cummings et al. 1987)), and faeces (Hammer et al. 1989), in inflammatory bowel disease colonic fermentation and absorption patterns may be so disrupted that SCFA become a minor component of the faecal stream with lactate, fumarate, succinate and malate making the major contribution to osmolarity (Vernia et al. 1988).

It is also important to recognize that substrate for colonic fermentation includes a considerable endogenous component (mucins and urea nitrogen) as well as exogenous fibre and poorly digested protein (Chacko \& Cummings, 1988). This may explain the discrepancy between estimated dietary 'fibre' intakes and the amount of fermentable substrate which needs to be consumed by luminal bacteria $(\sim 70 \mathrm{~g} / \mathrm{d})$ to produce the bacterial mass in normal human faeces (Smith \& Bryant, 1979).

SCFA play an important role in colonic water and electrolyte (mainly $\mathrm{Na}^{+}$) uptake which accompanies SCFA transport across jejunal and colonic mucosa. This transport involves both active transport of unprotonated SCFA $\left(\mathrm{Na}^{+}\right.$exchanged for $\mathrm{H}^{+}$and $\mathrm{Cl}^{-}$exchanged with butyrate) and passive diffusion of protonated SCFA down a concentration gradient (Ruppin et al. 1980; Binder \& Mehta, 1989; Watson et al. 1990). The existence of passive diffusion of SCFA may explain why inflammatory bowel disease (which reduces colonic uptake of organic anions) markedly depresses absorption of lactate, fumarate, malate and succinate which are predominantly absorbed by active transport processes, but has a lesser impact on SCFA uptake (Vernia $e t$ al. 1988). The capacity of the colonic luminal bacteria to ferment non-absorbed disaccharides such as lactulose (Hammer et al. 1989) and lactitol (Patil et al. 1987) and for the colon to absorb SCFA is limited ( $\sim 80 \mathrm{~g} /$ day) and above this level of intake osmotic diarrhoea will ensue. Thus, at lower levels of intake of fermentable carbohydrate, SCFA generated by luminal bacteria aid the process of dehydrating the faecal stream and salvage $90 \%$ of the water and electrolytes which enter the colon from the small intestine $(\sim 1350 \mathrm{ml} /$ day). Interference of this process by some antibiotics (most notably ampicillin, erythromycin, clindamycin and metronidazole) may explain the association of their use with diarrhoea in enterally fed patients (Keohane et al. 1983; Rees et al. 1985; Guenter et al. 1991). 
SCFA, notably butyrate, are also important for the epithelial cells of the caecum and colon. As a precursor for ketone production, not shared with acetate and propionate (Henning \& Hird, 1970; Windmueller \& Spaeth, 1978) butyrate appears to be preferentially used by colonocytes (Roediger, 1980) compared with other metabolic fuels (e.g. glucose and glutamine). It specifically promotes proliferation and differentiation of colonic epithelial crypt cells (Young \& Gibson, 1991; Scheppach et al. 1992), modulates the cell cycle by down-regulating $\mathrm{N}$-ras oncogene expression and the proliferative potential of cultured human colon tumour cell lines (Niles et al. 1988; Tanaka et al. 1989; Kruh et al. 1991), and induces cellular differentiation in terms of expression of surface hydrolases and glycosylated cell surface components (Siddiqui \& Kim, 1984), whilst reducing expression of surface tumour specific antigens (Niles et al. 1988).

It would be expected therefore that an intraluminal supply of butyrate is important for colonic repair and this has been demonstrated by Rombeau and colleagues (Kripke $\boldsymbol{e t}$ al. 1989 ) in relation to the promotion of healing of the rat colon after surgical resection and re-anastomosis. Chronic intraluminal delivery of butyrate increased the cellularity of the colonic epithelium and improved burst strength of the anastomotic wound (Rolandelli et al. 1986; Kripke et al. 1989). Intravenous SCFA, however, were trophic to the small intestinal but not the colonic mucosa (Koruda et al. 1988). Thus this is a unique aspect of luminal butyrate and contrasts with the role of other luminal nutrients such as glucose (Fernandez Lopez et al. 1992), amino acids (Egan \& Rennie, 1986) and glutamine (Windmueller, 1982) which appear to be supplied for metabolism by absorptive cells from arterial blood, rather than from the intestinal lumen.

The third important role of SCFA is in the regulation of colonic blood flow. Acetate, the major SCFA produced by fermentation, has the most marked stimulatory effect (Mortensen et al. 1990), although absorption of several other luminal nutrients, including glucose and glutamine, is accompanied by increased regional blood flow to the intestine (Qamar et al. 1986; Crissinger \& Burney, 1992; Flynn et al. 1992). It is therefore difficult to disentangle the contribution of direct metabolic trophism of the SCFA and the consequences of regional stimulation of the intestine through increased blood flow.

\section{THE CLINICAL SIGNIFICANCE OF SCFA SUPPLEMENTATION OF COLONIC LUMINAL CONTENTS}

Given the importance of SCFA for water and electrolyte transport, increased colonic supply might be thought to reduce diarrhoea. However, recent prospective trials have shown that supplementation of enteral formulae with fermentable fibre has little effect on the incidence of diarrhoea (Guenter et al. 1991). Benefits from the presence of luminal SCFA have been reported, however, and may relate to the maintenance of normal mucosal cellularity. The concept of 'bowel rest' following surgery or during inflammatory episodes of Crohn's disease was developed to suppress the activity of luminal aggressive factors such as bile and pancreatic secretions on inflamed or healing tissue. However, where part of the large intestine is surgically diverted from the intestinal luminal stream, even though these aggressive factors are absent from the lumen, diversion colitis can occur. Restoration of the continuity of the faecal stream by re-anastomosis has been shown to reduce colitis in the affected segment (Korelitz et al. 1984). This has led to the suggestion that the key luminal factor, whose absence may lead to colonic 'starvation', is butyrate, since its instillation into the diverted loop of intestine has been shown to reduce inflammation (Roediger, 1990). In the intact gut, Kasper and colleagues have demonstrated that 2 weeks of treatment with rectal enemas of $100 \mathrm{mmol} / 1$ sodium butyrate normalized the histological appearance of the distal colon in patients with steroid resistant ulcerative colitis and halved the frequency 
of defecation, presumably because the water absorbing function of the mucosa was restored (Scheppach et al. 1992). There is a clear need for studies of this type, in patients undergoing large bowel surgery, to determine if luminal irrigation at the time of surgery and postoperatively will influence outcome.

\section{CONCLUSIONS}

According to the criteria defined in Table 1, glutamine, arginine and related metabolites can only be defined as 'conditionally-essential' if they correct clinical abnormalities. The major conceptual dilemma in their definition as conditionally essential nutrients is that the human frame is capable of producing them in abundance. It can be argued that trauma causes the reductions in plasma and intracellular glutamine concentrations and in muscle protein synthesis, and that the flow of glutamine merely follows the direction of metabolic acidosis and associated cellular/plasma $\mathrm{Na}^{+}$and $\mathrm{K}^{+}$distribution. In other words, glutamine flows reflect a new metabolic set point, not that the set point results from glutamine deficiency. This point is important because supplements of compounds related to glutamine (ornithine and $\alpha$-ketoglutarate) have been shown to normalise post-surgical metabolism as effectively as supplements of glutamine itself, even though these compounds are not nutrients. It may therefore be safer to define these compounds as pharmaceutical agents, not as essential nutrients. For arginine, until the mechanisms of its effects are better understood, its definition as a conditionally essential nutrient remains problematic.

Purine and pyrimidine requirements are also difficult to define as there is little evidence to suggest essentiality, especially since the capacity for de novo synthesis is high. However, it is conceivable that in the period after injury it would be prudent to continue providing purines and pyrimidines as nutrients on the grounds that prior nutrient intake has suppressed the enzymes of the de novo pathway. Several studies have suggested beneficial effects of nucleotide supplementation on tissues which are undergoing rapid cell division or repair.

Short-chain fatty acids are the only nutrients which can be classed as essential on the grounds that organ function is impaired by their absence. This relates to the fact that no alternative pathway for butyrate synthesis exists apart from that provided by colonic luminal bacteria. The use of antibiotics and parenteral or low residue enteral nutrition in hospitalized patients will all lead to reduced SCFA production, compared to preadmission levels. As has been described, this can impair one aspect of organ function (water and electrolyte handling) and SCFA deficiency may be implicated in the aetiology of inflammatory bowel disease.

\section{REFERENCES}

Aisaki, K., Gross, S. S., Griffith, O. W. \& Levi, R. (1989). $\mathbf{N}^{\mathrm{C}}$-methylarginine, an inhibitor of endothelium-derived nitric oxide synthesis, is a potent pressor agent in the guinea pig: does nitric oxide regulate blood pressure in vivo? Biochemical and Biophysical Research Communications 160, 881-886.

Ardawi, M. S. M., Majzoub, M. F., Kateilah, S. M. \& Newsholme. E. A. (1991). Maximal activity of phosphatedependent glutaminase and glutamine metabolism in septic rats. Journal of Laboratory and Clinical Medicine $118,26-32$.

Ashford, A. J. \& Pain, V. M. (1986). Effect of diabetes on the rates of synthesis and degradation of ribosomes in rat muscle and liver in vivo. Journal of Biological Chemistry 261, 40594065.

Austgen, T. R., Chen, M. K., Flynn, T. C. \& Souba, W. W. (1991). The effects of endotoxin on the splanchnic metabolism of glutamine and related substrates. Journal of Trauma 31, 742-751.

Barbul, A. (1986). Arginine: biochemistry, physiology, and therapeutic implications. Journal of Parenteral and Enteral Nutrition 10, 227-238.

Barbul, A., Lazarou, S. A., Efron, D. T., Wasserkrug, H. L. \& Efron, G. (1990). Arginine enhances wound healing and lymphocyte immune responses in humans. Surgery 108, $331-337$. 
Bates, P. C., Grimble, G. K., Sparrow, M. P.\& Millward, D. J. (1983). Myofibrillar protein turnover. Synthesis of protein bound 3-methyl histidine, actin, myosin heavy-chain and aldolase in rat skeletal muscle in the fed and fasted state. Biochemical Journal 214, 593-605.

Batshaw, M. L., Walser, M.\& Brusilow, S. W. (1980). Plasma $\alpha$-ketoglutarate in urea cycle enzymopathies and its role as a harbinger of hyperammonemic coma. Pediatric Research 14, 1316-1319.

Bessey, P. Q., Watters, J. M., Aoki, T. T.\& Wilmore, D. W. (1984). Combined hormonal infusion simulates the metabolic response to injury. Annals of Surgery 200, 264-281.

Binder, H. J. \& Mehta, P. (1989). Short-chain fatty acids stimulate active sodium and chloride absorption in vitro in the rat distal colon. Gastroenterology $96,989.996$.

Boross, M., Kinsella, J., Cheng, L. \& Sacktor, B. (1986). Glucocorticoids and metabolic acidosis-induced renal transports of inorganic phosphate, calcium, and $\mathrm{NH}_{4}^{+}$. American Journal of Physiology 250, F827-F833.

Boughton-Smith, N. K., Deakin, A. M. \& Whittle, B. J. (1992). Actions of nitric oxide on the acute gastrointestinal damage induced by PAF in the rat. Agents \& Actions (Supplement), C3-C9.

Brocker, P., Sassard, F. \& Lods, J. C. (1985). [Effect of ornithine $\alpha$-ketoglutarate on blood levels of albumin and transferrin in undernourished elderly people in hospital.] Revue de Geriatrie 10, 233-236.

Brosnan, J. T. (1987). The 1986 Borden Award Lecture. The role of the kidney in amino acid metabolism and nutrition. Canadian Journal of Physiology and Pharmacology 65, 2355 2362.

Burge, J., McKnight, T., Mirtallo, J., Vargo, A., Choban, P.\& Flancbaum, L. (1992). Urinary urea plus ammonia approximates total urinary nitrogen in patients receiving nutrition support. Journal of Parenteral and Enteral Nutrition 16 (Suppl.) 26S.

Burrin, D. G., Shulman, R. J., Storm, M. C.\& Reeds, P. J. (1991). Glutamine or glutamic acid effects on intestinal growth and disacharidase activity in infant piglets receiving total parenteral nutrition. Journal of Parenteral and Enteral Nutrition 15, 262-266.

Calignano, A., Whittle, B. J. R.. Di Rosa. M. \& Moncada, S. (1992). Involvement of endogenous nitric oxide in the regulation of rat intestinal motility in vivo. European Journal of Pharmacology 229, 273-276.

Chacko, A. \& Cummings, J. H. (1988). Nitrogen losses from the human small bowel: obligatory losses and the effect of physical form of food. Gut 29, 809815 .

Cooper, H. L. (1972). RNA metabolism during lymphocyte activation. Transplantation Reviews 11, 3-38.

Crissinger, K. D. \& Burney, D. L. (1992). Influence of luminal nutrient composition on hemodynamics and oxygenation in developing intestine. American Journal of Physiology 263, G254-G260.

Cummings, J. H., Pomare, E. W., Branch, W. J., Naylor, C. P. E. \& MacFarlane, G. T. (1987). Short chain fatty acids in human large intestine, portal, hepatic and venous blood. Gut 28, 1221-1227.

Cynober, L. (1991). Ornithine $\alpha$-ketoglutarate in nutritional support. Nutrition 7, 313322.

Daly, J. M., Lieberman, M. D., Goldfine, J., Shou, J., Weintraub, F., Rosato, E. F. \& Lavin, P. (1992). Enteral nutrition with supplemental arginine, RNA, and omega-3 fatty acids in patients after operation: immunologic, metabolic, and clinical outcome. Surgery 112, 56-67.

Daly, J. M., Reynolds, J., Thom, A., Kinsley, L., Dietrick-Gallagher, M., Shou, J. \& Ruggieri, B. (1988). Immune and metabolic effects of arginine in the surgical patient. Annals of Surgery 208, 512-523.

Danielsen, M. \& Jackson, A. A. (1992). Limits of adaptation to a diet low in protein in normal man: urea kinetics. Clinical Science 83, 103-108.

Deutz. N. E. P., Dejong, C. H., Athanasas, G. \& Soeters, P. B. (1992a). Partial enterectomy in the rat does not diminish muscle glutamine production. Metabolism 41, 1343-1350.

Deutz, N. E. P., Reijven, P. L. M., Athanasas, G. \& Soeters, P. B. (1992b). Post-operative changes in hepatic, intestinal, splenic and muscle fluxes of amino acids in pigs. Clinical Science 83, 607-614.

D'Mello, J. P. F. (1982). Utilization of dietary purines and pyrimidines by non-ruminant animals. Proceedings of the Nutrition Society 41, 301-308.

Egan, C. J. \& Rennie, M. J. (1986). Relative importance of luminal and vascular amino acids for protein synthesis in rat jejunum. Journal of Physiology 378, 49P.

Elia, M. \& Livesey, G. (1983). Effects of ingested steak and infused leucine on forelimb metabolism in man and the fate of the carbon skeletons and amino groups of branched-chain amino acids. Clinical Science 64, 517-526.

Elsair, J., Poey, J., Isaad, H., Reggali, M., Bekri, T., Hattab, F. \& Spinner, C. (1978). Effect of arginine chlorhydrate on nitrogen balance during the three days following routine surgery in man. Biomedical Express 29, 312-317.

Fanslow, W. C., Kulkarni, A. D., Van Buren, C. T. \& Rudolph, F. B. (1988). Effect of nucleotide restriction and supplementation on resistance to experimental murine candidiasis. Journal of Parenteral and Enteral Nutrition 12, 49-52.

Fernandez Lopez, J. A., Casado, J., Argiles, J. M. \& Alemany, M. (1992). Intestinal handling of a glucose gavage by the rat. Molecular \& Cellular Biochemistry 113, 4353.

Fiddian Green, R. G. \& Baker, S. (1991). Nosocomial pneumonia in the critically ill: product of aspiration or translocation? Critical Care Medicine 19. 763-769.

Fine, A., Bennett, F. I. \& Alleyne, G. A. O. (1978). Effects of acute acid-base alterations on glutamine metabolism and renal ammoniagenesis in the dog. Clinical Science and Molecular Medicine 54, 503-508.

Fink, M. P. (1991). Gastrointestinal mucosal injury in experimental models of shock, trauma, and sepsis. Critical Care Medicine 19, 627-641. 
Flynn, W. J. J., Gosche, J. R. \& Garrison, R. N. (1992). Intestinal blood flow is restored with glutamine or glucose suffusion after hemorrhage. Journal of Surgical Research 52, 499--504.

Fong, Y. M., Albert, J. D., Tracey, K., Hesse, D. G., Calvano, S., Matthews, D. E. \& Lowry, S. F. (1991). The influence of substrate background on the acute metabolic response to epinephrine and cortisol. Journal of Trauma 31, 1467-1476.

Fox, A. D., Kripke, S. A., De Paula, J., Berman, J. M., Settle, R. G. \& Rombeau, J. L. (1988). Effect of a glutamine-supplemented enteral diet on methotrexate-induced enterocolitis. Journal of Parenteral and Enteral Nutrition 12, 325-331.

Fuller, S. J., Gaitanaki, C. J. \& Sugden, P. H. (1989). Effects of increasing extracellular pH on protein synthesis and protein degradation in the perfused working rat heart. Biochemical Journal 259, 173-179.

Furst, P., Albers, S. \& Stehle, P. (1987). Stress-induced intracellular glutamine depletion: the potential use of glutamine-containing peptides in parenteral nutrition. In Dipeptides as New Substrates in Nutation Therapy, pp. 117-136 [S. A. Adibi, W. Fekl and M. Oehmke, editors]. Munich: Karger.

Garibotto, G., Russo, R., Sala, M. R., Ancarani, P., Robaudo, C., Sofia, A., Deferrari, G. \& Tizianello, A. (1992). Muscle protein turnover and amino acid metabolism in patients with chronic renal failure. Mineral and Electrolyte Metabolism 18, 217-221.

Gaull, G., Sturman, J. A. \& Raiha, N. C. R. (1972). Development of mammalian sulfur metabolism: absence of cystathionase in human fetal tissue. Pediatric Research 6, 538-547.

Genchev, D. D., Kermekchiev, M. B. \& Hadjiolov, A. A. (1980). Free pyrimidine nucleotide pool of Ehrlich ascites-tumour cells. Compartmentation with respect to the synthesis of heterogeneous nuclear RNA and precursors to ribosomal RNA. Biochemical Journal 188, 85-90.

Ghiggeri, G. M., Ginevri, F., Cercignani, G., Oleggini, R., Garberi, A., Candiano, G., Atieri, P. \& Gusmano, R. (1990). Effect of dietary protein restriction on renal purines and purine-metabolizing enzymes in adriamycin nephrosis in rats: a mechanism for protection against acute proteinuria involving xanthine oxidase inhibition. Clinical Science 79,647 656.

Giesecke, D. \& Tiemeyer, W. (1982). Availability and metabolism of purines of single-cell proteins in monogastric animals. Proceedings of the Nutrition Society 41, 319-327.

Giesecke, K., Magnusson, I., Ahlberg, M., Hagenfeldt, L. \& Wahren, J. (1989). Protein and amino acid metabolism during early starvation as reflected by excretion of urea and methylhistidines. Metabolism 38 , $1196-1200$.

Golden, M. H. N., Jahoor, P. \& Jackson, A. A. (1982). Glutamine production rate and its contribution to urinary ammonia in normal man. Clinical Science 62, 299-305.

Goldstein, L., Boylan, J. M. \& Boyd, T. A. (1977). $\alpha$-Ketoglutarate regulation of glutamine transport and deamidation in renal mitochondria. Current Problems in Clinical Biochemistry 8, 273-279.

Goody, H. E. \& Ellem, K. A. O. (1975). Nutritional effect on precursor uptake and compartmentalization of intracellular pools in relation to RNA synthesis. Biochimica et Biophysica Acta 383, 30-39.

Greife, H. A. \& Molnar, S. (1983). $\left[{ }^{14} \mathrm{C}\right.$ tracer studies on the metabolism of nucleic acids in young rats, chickens and piglets. 1. Purine metabolism in young rats.] Zeitschrift für Tierphysiologie, Tierernährung und Futtermittelkunde 50, 79-91.

Greife, H. A., Molnar, S., Bos, T., Gussmann, M. \& Günther, K.-D. (1984). [N-metabolism in growing pigs receiving a bacterial protein supplement (Alcaligenes eutrophus) instead of soyabean meal.] Archiv für Tierernährung 34, 179 190.

Grimble, G. K. (1981). RNA Metabolism in Skeletal Muscle. PhD Thesis, University of London.

Grimble, G. K., Coudray-Lucas, C., Payne-James, J. J., Cynober, L., Ziegler, F. \& Silk, D. B. A. (1992). Augmentation of plasma arginine and glutamine by ornithine $\alpha$-ketoglutarate in healthy, enterally-fed volunteers. Proceedings of the Nutrition Society 51, 119A.

Grimble, G. K.\& Millward, D. J. (1977). The measurement of ribosomal ribonucleic acid synthesis in rat liver and skeletal muscle in vivo. Biochemical Society Transactions 5, 913-916.

Grimble, G. K., West, M. F. E., Acuti, A. B. C., Rees, R. G., Hunjan, M. K., Webster, J. D., Frost, P. G. \& Silk, D. B. A. (1988). Assessment of an automated chemiluminescence nitrogen analyzer for routine use in clinical nutrition. Journal of Parenteral and Enteral Nutrition 12, 100-106.

Gross, C. J., Stiles, J. E. \& Savaiano, D. A. (1988). Effect of nutritional state and allopurinol on purine metabolism in the rat small intestine. Biochimica et Biophysica Acta 966, 168-175.

Guedon, C., Schmitz, J., Lerebours, E., Metayer, J., Audran, E., Hemet, J. \& Colin, R. (1986). Decreased brush border hydrolase activities without gross morphologic changes in human intestinal mucosa after prolonged total parenteral nutrition of adults. Gastroenterology $90,373-378$

Guenter, P. A., Settle, R. G.. Perlmutter, S., Marino, P. L., DeSimone, G. A. \& Rolandelli, R. H. (1991). Tubefeeding related diarrhea in acutely-ill patients. Journal of Parenteral and Enteral Nutrition 15, $277-280$.

György, P. (1971). The uniqueness of human milk: biochemical aspects. American Journal of Clinical Nutrition 24. 970-975.

Hammarqvist, F., Stromberg, C., von der Decken, A., Vinnars, E. \& Wernerman, J. (1992). Biosynthetic human growth hormone preserves both muscle protein synthesis and the decrease in muscle-free glutamine, and improves whole-body nitrogen economy after operation. Annals of Surgery 216, 184-191.

Hammarqvist, F., Wernerman, J., Ali, R., von der Decken, A. \& Vinnars, E. (1988). Effects of glutamine supplementation to total parenteral nutrition after elective abdominal surgery. Clinical Nutrition 7 (Suppl.), 36. 
Hammarqvist, F., Wernerman, J., Ali, R., von der Decken, A. \& Vinnars, E. (1989a). Addition of glutamine to total parenteral nutrition after elective abdominal surgery spares free glutamine in muscle, counteracts the fall in muscle protein synthesis, and improves nitrogen balance. Annals of Surgery 209, 455-461.

Hammarqvist, F., Wernerman, J. \& Vinnars, E. (1989 b). Alpha-ketoglutarate added to post-operative total parenteral nutrition improves nitrogen balance and reduces the loss of free glutamine in skeletal muscle. Journal of Parenteral and Enteral Nutrition 13 (Suppl.), 6S.

Hammer, H. F., Santa Ana, C. A., Schiller, L. R. \& Fordtran, J. S. (1989). Studies of osmotic diarrhea induced in normal subjects by ingestion of polyethylene glycol and lactulose. Journal of Clinical Investigation 84, 1056-1062

Haussinger, D., Lamers. W. H. \& Moorman, A. F. (1992). Hepatocyte heterogeneity in the metabolism of amino acids and ammonia. Enzyme 46, 72-93.

Hegarty, J. E., Fairclough, P. D., Clark, M. L. \& Dawson, A. M. (1981). Jejunal water and electrolyte secretion induced by L-arginine in man. Gut 22, 108-113.

Helms, R. A., Christensen, M. L., Mauer, E. C. \& Storm, M. C. (1987). Comparison of a pediatric versus standard amino acid formulation in preterm neonates requiring parenteral nutrition. Journal of Pediatrics 110. $466-470$.

Henning, S. J. \& Hird, F. J. R. (1970). Concentrations and metabolism of volatile fatty acids in the fermentative organs of two species of kangaroo and the guinea-pig. British Journal of Nutrition 24, 145-155

Hill, J. M. (1975). Ribosomal RNA metabolism during renal hypertrophy. Evidence of decreased degradation of newly synthesized ribosomal RNA. Journal of Cell Biologv 64, 260265.

Hill, J. M., Ab, G. \& Malt, R. A. (1974). Ribonucleic acid labelling and nucleotide pools during compensatory renal hypertrophy. Biochemical Journal 144, 447-453.

Iijima, S., Tsujinaka, T., Kido, Y., Hayashida. Y.. Ishida, H., Homma, T., Yokoyama, H. \& Mori, T. (1993). Intravenous administration of nucleosides and a nucleotide mixture diminishes intestinal mucosal atrophy induced by total parenteral nutrition. Journal of Parenteral and Enteral Nutrition 17, 265-270.

Itoh, H., Kishi, T. \& Chibata, I. (1973). Comparative effects of casein and amino acid mixture simulating casein on growth and food intake in rats. Journal of Nutrition 103, 1709-1715.

Jackson. A. A. (1983). Aminoacids: essential and non-essential? Lancet i, 1034-1037.

Jackson, A. A.. Picou, D. \& Landman, J. (1984). The non-invasive measurement of urea kinetics in normal man by a constant infusion of ${ }^{15} \mathrm{~N}^{15} \mathrm{~N}$-urea. Human Nutrition: Clinical Nutrition 38, 339-354.

Jahoor, F., Jackson, A. A. \& Golden, M. H. N. (1988). In vivo metabolism of nitrogen precursors for urea synthesis in the postprandial rat. Annals of Nutrition \& Metabolism 32, 240244.

Jaziri, M., Migliore-Samour, D., Casabianca-Pignède, M.-R., Keddad, K., Morgat, J. L. \& Jollès, P. (1992). Specific binding sites on human phagocytic blood cells for Gly-Leu-Phe and Val-Glu-Pro-Ile-Pro-Tyr, immunostimulating peptides from human milk proteins. Biochimica et Biophysica Acta 1160, 251 - 261.

Jeevanandam, M., Ali, M. R. \& Petersen, S. R. (1992). Substrate and hormonal changes due to dietary supplementation with ornithine $\alpha$-ketoglutarate (OKG) in critically ill trauma victims. Clinical Nutrition 11 (Suppl.), 26.

Jeevanandam, M., Ali, M. R., Ramias, L. \& Schiller, W. R. (1991). Efficacy of ornithine $\alpha$-ketoglutarate (OKG) as a dietary supplement in growing rats. Clinical Nutrition 10, 155-161.

Jepson, M. M., Bates, P. C., Broadbent, P., Pell, J. M. \& Millward, D. J. (1988). Relationship between glutamine concentration and protein synthesis in rat skeletal muscle. American Journal of Physiology. 255, El66-E172.

Jimenez, J., Boza, J., Suarez, M. D. \& Gil, A. (1992). Changes in fatty acid profiles of red blood cell membranes mediated by dietary nucleotides in weanling rats. Journal of Pediatric Gastroenterology \& Nutrition 14, $293-299$.

Karatzas, T., Scopa, S., Tsoni, I., Panagopoulos, K., Spiliopolou, I., Moschos, S., Vagianos, K. \& Kalfarentzos, F. (1991). Effect of glutamine on intestinal mucosal integrity and bacterial translocation after abdominal radiation. Clinical Nutrition 10, 199-205.

Keohane, P. P., Attrill, H., Jones, B. J. M., Brown, B., Frost, P. \& Silk, D. B. A. (1983). The roles of lactose and Clostridium difficile in the pathogenesis of enteral feeding associated diarrhoea. Clinical Nutrition 1, $259-264$.

Kies, C. (1972). Nonspecific nitrogen in the nutrition of human beings. Federation Proceedings 31, 1172-1177.

King, P. A., Goldstein, L. \& Newsholme, E. A. (1983). Glutamine synthetase activity of muscle in acidosis. Biochemical Journal 216, 523525.

Kirk, S. J. \& Barbul, A. (1990). Role of arginine in trauma, sepsis, and immunity. Journal of Parenteral and Enteral Nutrition 14 (5, Suppl.), 226S-229S.

Klimberg, V. S., Salloum, R. M., Kasper. M., Plumley, D. A., Dolson, D. J., Hautamaki, R. D., Mendenhall, W. R., Bova, F. C., Bland, K. I., Copeland, E. M. \& Souba, W. W. (1990a). Oral glutamine accelerates healing of the small intestine and improves outcome after whole abdominal radiation. Archives of Surgery 125, $1040-1047$.

Klimberg, V. S., Souba, W. W., Dolson, D. J., Salloum, R. M., Hautamaki, R. D., Plumley, D. A., Mendenhall, W. M., Bova, F. J., Khan, S. R., Hackett, R. L., Bland, K. I. \& Copeland, E. M. (1990b). Prophylactic glutamine protects the intestinal mucosa from radiation injury. Cancer 66, 62- 68.

Konstantinides, F. N., Konstantinides, N. N., Li, J. C., Myaya, M. E. \& Cerra, F. B. (1991). Urinary urea nitrogen: too insensitive for calculating nitrogen balance studies in surgical clinical nutrition. Journal of Parenteral and Enteral Nutrition 15, 189-193. 
Koruda, M. J., Rolandelli, R. H., Settle, R. G., Zimmaro, D. M. \& Rombeau, J. L. (1988). Effect of parenteral nutrition supplemented with short-chain fatty acids on adaptation to massive small bowel resection. Gastroenterology 95, 715-720.

Korelitz, B. I., Cheskin, L. J., Sohn, N. \& Sommers, S. C. (1984). Proctitis after fecal diversion in Crohn's disease and its elimination with reanastomosis: implications for surgical management. Gastroenterology 87, $710-713$.

Krassowski, J., Rousselle, J., Maeder, E. \& Felber, J-P. (1981). The effect of ornithine $\alpha$-ketoglutarate on insulin and glucagon secretion in normal subjects. Acta Endocrinologica 98, 252-255.

Kripke, S. A., Fox, A. D., Berman, J. M., Settle, R. G. \& Rombeau, J. L. (1989). Stimulation of intestinal mucosal growth with intracolonic infusion of short-chain fatty acids. Journal of Parenteral and Enteral Nutrition 13 , 109-116.

Kruh. J., Defer, N. \& Tichonicky, L. (1991). Molecular and cellular effects of sodium butyrate. In Short-chain Fatty Acids: metabolism and clinical importance (10th Ross conference on medical research), pp. 4550 [A. F. Roche, editor]. Columbus, $\mathrm{OH}$ : Ross Laboratories.

Kubes, P. (1992). Nitric oxide modulates epithelial permeability in the feline small intestine. American Journal of Physiology 262. G1138 G1142.

Kubes, P. (1993). Ischemia-reperfusion in feline small intestine: a role for nitric oxide. American Journal of Physiology 264, G143-G149.

Kulkarni, A. D., Fanslow, W. C., Rudolph, F. B. \& Van Buren, C. T. (1986). Effect of dietary nucleotides on response to bacterial infections. Journal of Parenteral and Enteral Nutrition 10, 169-171.

Laidlaw, S. A. \& Kopple, J. D. (1987). Newer concepts of the indispensable amino acids. American Journal of Clinical Nutrition 46, 593-605.

Lambert, P. (1982). Effets de l'a-Cétoglutarate d'ornithine sur les sécrétions d'insuline, d'hormone somatotrope, de glucagon et de cortisol dans la cirrhose alcoolique. $\mathrm{PhD}$ Thesis, Université de Montpellier.

Laurent, G. J., Sparrow, M. P. \& Millward, D. J. (1978). Turnover of muscle protein in the fowl. 2. Changes in rates of protein synthesis and breakdown during hypertrophy of the anterior and posterior latissimus dorsi muscles. Biochemical Journal 176, 407- 417.

Leander, U., Fürst, P., Vesterberg, K. \& Vinnars, E. (1985). Nitrogen sparing effect of ornicetil ${ }^{\mathrm{R}}$ in the immediate postoperative state: clinical biochemistry and nitrogen balance. Clinical Nutrition 4, 43- 51

Lecointre, C. L. \& Dailly, R. (1981). [Stimulation of growth hormone by ornithine in pediatric pathology: study on the response of insulin.] Ouest Médical 34, 1197-1200.

LeLeiko, N. S., Bronstein, A. D., Baliga, B. S. \& Munro, H. N. (1983). De novo purine nucleotide synthesis in the rat small and large intestine: effect of dietary protein and purines. Journal of Pediatric Gastroenterology \& Nutrition 2, 313-319.

LeLciko, N. S., Bronstein, A. D. \& Munro, H. N. (1979). Effect of dietary purines on de novo synthesis of purine nucleotides in the small intestinal mucosa. Pediatric Research 13, 403.

Liu, S. Y., Leighton, T., Davis, I., Klein, S., Lippmann, M. \& Bongard, F. (1991). Prospective analysis of cardiopulmonary responses to laparoscopic cholecystectomy. Journal of Laparoendoscopic Surgery 1, $241-246$.

Loeb, J. N. \& Yeung, L. L. (1975). Synthesis and degradation of ribosomal RNA in regenerating liver. Journal of Experimental Medicine 142, 575-587.

Losman, M. J. \& Harley, E. H. (1978). Evidence for compartmentation of uridine nucleotide pools in rat hepatoma cells. Biochimica et Biophysica Acta 521, 762769.

Lowry, M. \& Ross, B. D. (1980). Activation of oxoglutarate dehydrogenase in the kidney in response to acute acidosis. Biochemical Journal 190, 771-780.

Lund, P. (1980). Glutamine metabolism in the rat. FEBS Letters 117 (Suppl.), K86-K92.

MacDonald, M. L., Rogers, Q. R. \& Morris, J. G. (1984). Nutrition of the domestic cat, a mammalian carnivore. Annual Review of Nutrition 4, 521-562.

May, R. C., Kelly, R. A. \& Mitch. W. E. (1986). Metabolic acidosis stimulates protein degradation in rat muscle by a glucocorticoid-dependent mechanism. Journal of Clinical Investigation 77, 614-621.

Merimee, T. J., Rabinowitz, D. \& Fineberg, S. E. (1969). Arginine-initiated release of human growth hormone. New England Journal of Medicine 280, 1434-1438.

Midtvedt, A.-C. \& Midtvedt, T. (1992). Production of short chain fatty acids by the intestinal microflora during the first 2 years of human life. Journal of Pediatric Gastroenterology \& Nutrition 15, $395-403$.

Miller, M.J., Zhang, X. J., Sadowska Krowicka, H., Chotinaruemol, S., McIntyre, J. A., Clark, D. A. \& Bustamante, S. A. (1993). Nitric oxide release in response to gut injury. Scandanavian Journal of Gastroenterology 28, 149-154.

Millward, D. J., Garlick, P. J., Stewart, R. J. C., Nnanyelugo, D. O. \& Waterlow, J. C. (1975). Skeletal-muscle growth and protein turnover. Biochemical Journal 150, 235-243.

Millward, D. J., Jackson, A. A., Price, G. \& Rivers, J. P. W. (1989). Human amino acid and protein requirements: current dilemmas and uncertainties. Nutrition Research Reviews 2, 109-132.

Moran, B. J. \& Jackson, A. A. (1990). ${ }^{15} \mathrm{~N}$-urea metabolism in the functioning human colon: luminal hydrolysis and mucosal permeability. Gut 31, 454-457.

Morgan, H. E., Siehl, D., Chua, B. H. L. \& Lautensack-Belser, N. (1985). Faster protein and ribosome synthesis in hypertrophying heart. Basic Research in Cardiology 80 (Suppl. 2), 115-118.

Moritoki, H., Takeuchi, S., Hisayama, T. \& Kondoh, W. (1992). Nitric-oxide synthase responsible for L-arginine- 
induced relaxation of rat aortic rings in vitro may be an inducible type. British Journal of Pharmacology 107. $361-366$.

Mortensen, F. V., Nielsen, H., Mulvany, M. J. \& Hessov, I. (1990). Short chain fatty acids dilate isolated human colonic resistance arteries. Gut 31, $1391 \cdot 1394$.

Munro, H. N. (1964). An introduction to nutritional aspects of protein metabolism. In Mammalian Protein Metabolism, Vol. 2, pp. 339 [H. N. Munro and J. B. Allison, editors]. New York: Academic Press.

Nakagawa, I., Takahashi, T., Suzuki, T. \& Kobayashi, K. (1963). Amino acid requirements of children: minimal needs of tryptophan, arginine and histidine based on nitrogen balance method. Journal of Nutrition 80, 305310.

Newsholme, E. A., Crabtree, B. \& Ardawi, M. S. M. (1985). Glutamine metabolism in lymphocytes: its biochemical, physiological and clinical importance. Quarterly Journal of Experimental Physiology 70, 473489.

Newsholme, E. A. \& Parry-Billings, M. (1990). Properties of glutamine release from muscle and its importance for the immune system. Journal of Parenteral and Enteral Nutrition 14 (4. Suppl.), 63S-67S.

Newsholme, P. \& Newsholme, E. A. (1989). Rates of utilization of glucose, glutamine and oleate and formation of end-products by mouse peritoneal macrophages in culture. Biochemical Journal 261, 211- 218.

Niles, R. M., Wilhelm, S. A., Thomas, P. \& Zamcheck, N. (1988). The effect of sodium butyrate and retinoic acid on growth and CEA production in a series of human colorectal tumor cell lines representing different states of differentiation. Cancer Investigation 6, 3945.

Nunez, M. C., Ayudarte, M. V., Morales, D., Suarez, M. D. \& Gil, A. (1990). Effect of dietary nucleotides on intestinal repair in rats with experimental chronic diarrhea. Journal of Parenteral and Enteral Nutrition 14, 598604.

O’Dwyer, S. T., Michiè, H. R., Ziegler, T. R., Revhaug, A., Smith, R. J. \& Wilmorc, D. W. (1988). A single dose of endotoxin increases intestinal permcability in healthy humans. Archives of Surgerv 123, 14591464.

Ogoshi, S., Iwasa, M., Kitagawa, S., Ohmori, Y., Mizobuchi, S., Iwasa, Y. \& Tamiya, T. (1988). Effects of total parenteral nutrition with nucleoside and nucleotide mixture on D-galactosamine-induced liver injury in rats. Journal of Parenteral and Enteral Nutrition 12, 53-57.

Ogoshi, S., Iwasa, M., Mizobuchi, S., Iwasa, Y., Martiz, A. \& Tamiya, T. (1990). Effect of a nucleoside and nucleotide mixture on protein metabolism in rats given total parenteral nutrition after $70 \%$ hepatectomy. In Nutritional Support in Organ Failure, pp. 309-317 [T. Tanaka and A. Okada, editors]. Amsterdam: Elsevier.

Ogoshi, S., Iwasa, M., Yonezawa, T. \& Tamiya, T. (1985). Effect of nucleotides and nucleoside mixture on rats given total parenteral nutrition after 70\% hepatectomy. Journal of Parenteral and Enteral Nutrition 9, $339-342$.

Ove, P., Adams. R. L. P., Abrams, R. \& Lieberman. I. (1966). Liver uridine triphosphate after partial hepatectomy. Biochimica et Biophysica Acta 123, 419-421.

Owen, E. E. \& Robinson, R. R. (1963). Amino acid extraction and ammonia metabolism by the human kidney during prolonged administration of ammonium chloride. Journal of Clinical Investigation 42, 263--276

Owen, O. E., Felig, P., Morgan, A. P., Wahren, J. \& Cahill, G. F. (1969). Liver and kidney metabolism during prolonged starvation. Journal of Clinical Investigation 48, 574-583.

Palmer, R. M. J., Ferrige, A. G. \& Moncada, S. (1987). Nitric oxide release accounts for the biological activity of endothelium-derived relaxing factor. Nature 327, 524-526.

Patil. D. H., Grimble, G. K. \& Silk, D. B. A. (1987). Lactitol, a new hydrogenated lactose derivative: intestinal absorption and laxative threshold in normal human subjects. British Journal of Nutrition 57, 195199.

Pitts, R. F. \& Pilkington, L.-A. (1966). The relation between plasma concentrations of glutamine and glycine and utilization of their nitrogens as sources of urinary ammonia. Journal of Clinical Investigation 45, 86-93.

Pollack, P. F., Koldovsky, O. \& Nishioka, K. (1992). Polyamines in human and rat milk and in infant formulas. American Journal of Clinical Nutrition 56, 371-375.

Ponting, G. A., Ward, H. C., Halliday, D. \& Sim, A. J. (1990). Protein and energy metabolism with biosynthetic human growth hormone in patients on full intravenous nutritional support. Journal of Parenteral and Enteral Nutrition 14, 437. 441.

Preedy, V. R. \& Garlick, P. J. (1988). The influence of restraint and infusion on rates of muscle protein synthesis in the rat. Effect of altered respiratory function. Biochemical Journal 251, 577-580.

Qamar, M. I., Read, A. E. \& Mountford. R. (1986). Increased superior mesenteric artery blood flow after glucose but not lactulose ingestion. Quarterly Journal of Medicine 60, 893-896.

Raybould, H. E. (1991). Capsaicin-sensitive vagal afferents and CCK in inhibition of gastric motor function induced by intestinal nutrients. Peptides 12, 1279-1283.

Reaich, D., Channon, S. M., Scrimgeour. C. M. \& Goodship, T. H. J. (1992). Ammonium chloride-induced acidosis increases protein breakdown and amino acid oxidation in humans. American Journal of Physiology 263, E735-E739.

Rees, R. G. P., Keohane, P. P., Grimble, G. K., Frost, P. G., Attrill, H. \& Silk, D. B. A. (1985). Tolerance of elemental diet administered without starter regimen. British Medical Journal 290, 1869-1870.

Rennie, M. J., Hundal. H. S., Babij, P., MacLennan, P., Taylor, P. M., Watt, P. W., Jepson, M. M. \& Millward, D. J. (1986). Characteristics of a glutamine carrier in skeletal muscle have important consequences for nitrogen loss in injury, infection, and chronic disease. Lancer ii, 1008-1012.

Richter, G. C., Levine, G. M. \& Shiau, Y.-F. (1983). Effects of luminal glucose versus nonnutritive infusates on jejunal mass and absorption in the rat. Gastroenterology 85, $1105-1112$.

Roden, M., Paterson, A. R. P.\& Turnheim, K. (1991). Sodium-dependent nucleoside transport in rabbit intestinal epithelium. Gastroenterology 100, $1553 \cdot 1562$. 
Roediger, W. E. W. (1980). Role of anaerobic bacteria in the metabolic welfare of the colonic mucosa in man. Gut 21, 793798.

Roediger, W. E. W. (1990). The starved colon - diminished mucosal nutrition. diminished absorption. and colitis. Diseases of the Colon \& Rectum 33. 858-862.

Rolandelli, R. H., Koruda, M. J., Settle, R. G. \& Rombeau, J. L. (1986). Effects of intraluminal infusion of shortchain fatty acids on the healing of colonic anastomoses in the rat. Surgery 100, 198-204.

Romain, N., Dandrifosse, G., Jeusette, D. F. \& Forget, P. (1992). Polyamine concentration in rat milk and food, human milk, and infant formulas. Pediatric Research 32, 58-63.

Rose, W. C. (1937). The nutritive significance of the amino acids and certain related compounds. Science 86 , 298-300.

Rose, W. C. (1957). The amino acid requirements of adult man. Nutrition Abstracts and Reviews 27, $631-647$.

Roth, E., Funovics, J., Mühlbacher, F., Schemper, M., Mauritz, W., Sporn, P. \& Fritsch, A. (1982). Metabolic disorders in severe abdominal sepsis: glutamine deficiency in skeletal muscle. Clinical Nutrition 1, 25-41.

Ruppin, H., Bar-Meir, S., Soergel, K. H., Wood, C. M. \& Schmitt, M. G. (1980). Absorption of short chain fatty acids by the colon. Gastroenterology 78, 1500-1507.

Rustom, R., Jackson, M. J., Critchley, M. \& Bone, J. M. (1992). Tubular metabolism of aprotinin 99mTc and urinary ammonia: effects of proteinuria. Mineral and Electrolyte Metabolism 18, 108-112.

Savaiano, D. A. \& Clifford, A. J. (1981). Adenine, the precursor of nucleic acids in intestinal cells unable to synthesize purines de novo. Journal of Nutrition 111, 1816-1822.

Savaiano, D. A., Ho, C. Y., Chu, V. \& Clifford, A. J. (1980). Metabolism of orally and intravenously administered purines in rats. Journal of Nutrition 110, 1793-1804.

Schanker, L. S., Jeffrey, J. J. \& Tocco, D. J. (1963). Interaction of purines with the pyrimidine transport process of the small intestine. Biochemical Pharmacologv 12, 1047-1053.

Scharrer, E., Stubenhofer, L., Tiemeyer, W. \& Bindl, C. (1984). Active pyrimidine absorption by chicken colon. Comparative Biochemistry \& Physiology A 77, 85-88.

Scheppach, W., Bartram, P., Richter, A., Richter, F., Liepold, H., Dusel, G., Hofstetter, G., Ruthlein, J. \& Kasper, H. (1992). Effect of short-chain fatty acids on the human colonic mucosa in vitro. Journal of Parenteral and Enteral Nutrition 16, 43-48.

Scheppach, W., Sommer, H., Kirchner, T., Paganelli, G.-M., Bartram, P., Christl, S., Richter, F., Duscl, G. \& Kasper, H. (1992). Effect of butyrate enemas on the colonic mucosa in distal ulcerative colitis. Gastroenterology $103,51-56$.

Seifter, E., Rettura, G. \& Barbul, A. (1978). Arginine, an essential amino acid for injured rats. Surgery 84, $224-230$.

Siddiqui, B. \& Kim, Y. S. (1984). Effects of sodium butyrate, dimethyl sulfoxide, and retinoic acid on glycolipids of human rectal adenocarcinoma cells. Cancer Research 44, 1648-1652.

Smith, C. J. \& Bryant, M. P. (1979). Introduction to metabolic activities of intestinal bacteria. American Journal of Clinical Nutrition 32, $149-157$.

Snyderman, S. E., Holt, L. E., Dancis, J., Roitman, E., Boyer, A. \& Balis, M. E. (1962). "Unessential" nitrogen: a limiting factor for human growth. Journal of Nutrition 78, 57-72.

Soeters, P. B. \& van Leeuwen, P. A. M. (1986). [Ammonia and glutamine metabolism of the intestine. The effect of lactulose and neomycin.] Infusionstherapie und Klinische Ernährung 13, 186-190.

Sonoda, T. \& Tatibana, M. (1978). Metabolic fate of pyrimidines and purines in dietary nucleic acids ingested by mice. Biochimica et Biophysica Acta 521, 55-66.

Souba, W. W. (1993). Intestinal glutamine metabolism and nutrition. Journal of Nutritional Biochemistry 4, $2-9$.

Souba, W. W., Klimberg, V. S., Plumley, D. A., Salloum, R. M., Flynn, T. C., Bland, K. I. \& Copeland, E. M. (1990). The role of glutamine in maintaining a healthy gut and supporting the metabolic response to injury and infection. Journal of Surgical Research 48, 383-387.

Souba, W. W., Scott, T. E. \& Wilmore, D. W. (1985a). Intestinal consumption of intravenously administered fuels. Journal of Parenteral and Enteral Nutrition 9, 18.22.

Souba, W. W., Smith, R. J. \& Wilmore, D. W. (1985b). Glutamine metabolism by the intestinal tract. Journal of Parenteral and Enteral Nutrition 9, 608617.

Souba, W. W. \& Wilmore, D. W. (1983). Postoperative alterations of arteriovenous exchange of amino acids across the gastrointestinal tract. Surgery 94, 342-350.

Squires, E. J. \& Brosnan, J. T. (1983). Measurements of the turnover rate of glutamine in normal and acidotic rats. Biochemical Journal 210, 277- 280.

Stehle, P., Zander, J., Mertes, N., Albers, S., Puchstein, Ch., Lawin, P. \& Fürst, P. (1989). Effect of parenteral glutamine peptide supplements on muscle glutamine loss and nitrogen balance after major surgery. Lancet i, 231-233.

Szondy. Z. \& Newsholme. E. A. (1990). The effect of various concentrations of nucleobases, nucleosides or glutamine on the incorporation of $\left[{ }^{3} \mathrm{H}\right]$ thymidine into DNA in rat mesenteric-lymph-node lymphocytes stimulated by phytohaemagglutinin. Biochemical Journal 270, $437-440$.

Tamada, H., Nezu, R., Imamura, I., Matsuo, Y., Takagi, Y., Kamata, S. \& Okada, A. (1992). The dipeptide alanyl-glutamine prevents intestinal mucosal atrophy in parenterally fed rats. Journal of Parenteral and Enteral Nutrition 16, 110-116. 
Tanaka, Y., Bush, K. K.. Klauck, T. M. \& Higgins, P. J. (1989). Enhancement of butyrate-induced differentiation of HT-29 human colon carcinoma cells by 1,25-dihydroxyvitamin $\mathrm{D}_{3}$. Biochemical Pharmacology 38 . 3859-3865.

Tizianello. A. G., De Ferrari, G., Garibotto, G. \& Gurreri, G. (1978). Effects of chronic renal insufficiency and metabolic acidosis on glutamine metabolism in man. Clinical Science \& Molecular Medicine 55. 391397.

Trémolières, J., Scheggia, E. \& Flament, C. (1972). [Effects of ornithine $\alpha$-ketoglutarate on nitrogen balance and the rate of oxidation of ethanol.] Cahiers de Nutrition et de Diététique 7, 297302.

Uauy, R., Stringel, G., Thomas, R. \& Quan, R. (1990). Effect of dietary nucleosides on growth and maturation of the developing gut in the rat. Journal of Pediatric Gastroenterology \& Nutrition 10, 497503.

Vallance, P., Collier, J. \& Moncada, S. (1989). Effects of endothelium-derived nitric oxide on peripheral arteriolar tone in man. Lancet ii, 997--999.

van Berlo, C. L. H., van Leeuwen, P. A. M. \& Soeters, P. B. (1988). Porcine intestinal ammonia liberation. Influence of food intake, lactulose and neomycin treatment. Journal of Hepatology 7. 250257.

van der Hulst, R. R., van Kreel, B. K.. Von Meyenfeldt, M. F., Brummer, R. J.. Arends, J. W., Deutz, N. E. \& Soeters, P. B. (1993). Glutamine and the preservation of gut integrity. Lancet 341, 13631365

Vernia, P., Gnaedinger, A., Hauck, W. \& Breuer, R. 1. (1988). Organic anions and the diarrhea of inflammatory bowel disease. Digestive Diseases \& Sciences 33, 1353-1358.

Vinay, P., Allignet. E., Pichette, C., Watford. M., Lemieux, G. \& Gougoux, A. (1980). Changes in renal metabolite profile and ammoniagenesis during acute and chronic metabolic acidosis in dog and rat. Kidney International 17, 312-325

Visek, W. J. (1986). Arginine needs, physiological state and usual diets. A reevaluation. Journal of Nutrition 116. $36-46$.

Watson, A. J. M., Elliott, E. J., Rolston, D. D. K.. Borodo, M. M., Farthing. M. J. G. \& Fairclough. P. D. (1990). Acetate absorption in the normal and secreting rat jejunum. Gut 31, 170-174.

Welbourne, T.. Weber, M. \& Bank, N. (1972). The effect of glutamine administration on urinary ammonium excretion in normal subjects and patients with renal disease. Journal of Clinical Investigation 51, 1852 -1860.

Wernerman. J., Brandt, R., Strandell, T., Allgen. L.-G. \& Vinnars, E. (1985). The effect of stress hormones on the interorgan flux of amino acids and on the concentration of free amino acids in skeletal muscle. Clinical Nutrition 4, 207216.

Wernerman, J., Hammarqvist. F. \& Vinnars, E. (1990). $x$-Ketoglutarate and postoperative muscle catabolism. Lancet 335, 701703.

Wernerman, J., Hammarqvist, F., von der Decken, A. \& Vinnars, E. (1987). Ornithine $\alpha$-ketoglutarate improves skeletal muscle protein synthesis as assessed by ribosome analysis and nitrogen use after surgery. Annals of Surgery 206, 674678.

Wiegers, U., Kramer, G., Klapproth, K.\& Hilz, H. (1976). Separate pyrimidine-nucleotide pools for messengerRNA and ribosomal-RNA synthesis in HeLa S3 cclls. European Journal of Biochemistry 64, 535540.

Wilmore, D. W., Moylan, J. A., Bristow. B. F., Mason, A. D. \& Pruitt, B. A. (1974). Anabolic effects of human growth hormone and high caloric feedings following thermal injury. Surgery G.inecology \& Obsterrics 138, 875884 .

Wilmore, D. W., Smith, R. J., O'Dwyer, S. T., Jacobs, D. O.. Ziegler, T. R. \& Wang, X.-D. (1988). The gut: a central organ after surgical stress. Surgery 104, 917-923.

Windmueller, H. G. (1982). Glutamine utilization by the small intestine. Advances in Enzymolog. 53, $201-237$.

Windmueller, H. G. \& Spaeth, A. E. (1978). Identification of ketone bodies and glutamine as the major respiratory fuels in vivo for postabsorptive rat small intestine. Journal of Biological Chemistry 253, 69-76.

Wolfe, H. M., Sokol, R. J., Dombrowski, M. P., Bottoms, S. F. \& Norman, G. S. (1989). Increased neonatal urinary ammonia: a marker for in utero caloric deprivation? American Journal of Perinatolog. 6, 47.

Wu, G. \& Greene, L. W. (1992). Glutamine and glucose metabolism in bovine blood lymphocytes. Comparative Biochemistry and Physiology B 103, 821825.

Young, G. P. \& Gibson, P. (1991). Contrasting effects of butyrate on proliferation and differentiation of normal and neoplastic cells. In Short-chain Fatty Acids: metabolism and clinical importance (IOth Ross conference on medical research), pp. 50-55 [A. F. Roche, editor]. Columbus, OH: Ross Laboratories.

Ziegler, F., Coudray-Lucas, C., Jardel, A., Lasnicr, E. L., Le Boucher, J., Ekindjian, O. \& Cynober, L. (1992). Ornithine $\alpha$-ketoglutarate and glutamine supplementation during refeeding of food-deprived rats. Journal of Parenteral and Enteral Nutrition 16, 505-510.

Ziegler, T. R., Young, L. S., Manson, J. McK.\& Wilmore, D. W. (1988). Metabolic effects of recombinant human growth hormone in patients receiving parenteral nutrition. Amals of Surgery 208, 6-16.

Zöllner, N. (1982). Purine and pyrimidine metabolism. Proceedings of the Nutrition Society 41. 329-342. 